\title{
The Relationship between Biodiversity and Productivity in Permanent Grasslands and in Ley System
}

\author{
Dissertation \\ to obtain the $\mathrm{Ph}$. D. degree \\ in the Faculty of Agricultural Sciences, \\ Georg-August-University Göttingen, Germany
}

\author{
presented by \\ Taher A. Assaf \\ born in Irbid, Jordan
}

Göttingen, May 2008 
D7

1. Name of referee: Prof. Dr. Johannes Isselstein

2. Name of co-referee: Prof. Dr. Wolfram Beyschlag

Date of dissertation: $\quad 21.05 .2008$ 


\section{Dedication}

I wish to dedicate this thesis to:

\section{my late mother,}

my source of inspiration. Although she is not here, I always feel her presence, that used to urge me to achieve my goals in life.

\section{my wife Enas,}

my best friend and partner in life, who kept body and soul together during the creation of this work.

and

\section{my little daughter Toleen,}

who could put a smile on my face whenever I have had a hard time. 


\section{TABLE OF CONTENTS}

TABLE OF CONTENTS

LIST OF TABLES $\quad$ iii

LIST OF FIGURES

ACKNOWLEDGEMENTS vi

SUMMARY vii

$1 \quad$ INTRODUCTION 1

1.1 Preface 1

1.2 Biodiversity measurements 2

1.3 Biodiversity-productivity relationship in natural plant communities 3

1.4 The relationship between biodiversity and productivity in ley system 5

$\begin{array}{lll}1.5 & \text { Objectives and hypotheses }\end{array}$

Natural and semi-natural grasslands 6

Ley system $\quad 7$

2 The Relationship Between Plant Diversity and Productivity of Natural and $\begin{array}{ll}\text { Semi-natural Grasslands } & 8\end{array}$

2.1 Abstract $\quad 8$

$\begin{array}{lll}2.2 & \text { Introduction } & 8\end{array}$

2.3 Materials and methods 11

$\begin{array}{lll}2.4 & \text { Results } & 14\end{array}$

$\begin{array}{lll}2.5 & \text { Discussion } & 19\end{array}$

2.6 Conclusions 21

3 The Effect of Dandelion (Taraxacum officinale Web.) as a Constituent of Seed Mixtures on Herbage Production and Weed Infestation of Perennial Ryegrass-white Clover Swards $\quad 22$

3.1 Abstract 22

3.2 Introduction 22

$\begin{array}{lll}3.3 & \text { Materials and methods } & 24\end{array}$ 
$\begin{array}{lll}3.4 & \text { Results } & 27\end{array}$

3.5 Discussion 33

3.6 Conclusions 36

4 Contribution of Dandelion (Taraxacum officinale Weber) to The Mineral Herbage Yield (Ca, Mg, K, P, and $\mathrm{Na}$ ) of Perennial Ryegrass-white Clover Mixture 38

4.1 Abstract 38

$\begin{array}{lll}4.2 & \text { Introduction } & 38\end{array}$

$\begin{array}{lll}4.3 & \text { Materials and methods } & 40\end{array}$

$\begin{array}{lll}4.4 & \text { Results } & 43\end{array}$

4.5 Discussion 48

$\begin{array}{lll}4.6 & \text { Conclusions } & 50\end{array}$

$5 \quad$ GENERAL DISCUSSION 51

6 REFRENCES 56

$\begin{array}{lll}7 & \text { PUPLICATIONS } & 66\end{array}$

$8 \quad$ CURRICULUM VITAE 


\section{LIST OF TABLES}

Table 2.1

Table 2.2

Table 2.3

Table 2.4

Table 3.1

Table 3.2

Table 3.3

Table 4.1

Table 4.2

Table 4.3
Species and soil characteristic (average of 18 quadrates) of the semi-natural grasslands.

natural grasslands.

within-site level.

within-site level.

Average air temperature $\left({ }^{\circ} \mathrm{C}\right.$ at $\left.2.0 \mathrm{~m}\right)$ and precipitation $(\mathrm{mm})$

expressed as quarterly values for the study area.

$F$ values and level of significances of ANOVA for effects of sward composition (Sward), nitrogen fertilizer rates $(\mathrm{N})$, and year (Year) on herbage, non-sown species and $\mathrm{N}$ yield.

Relative yield total (RYT) of ryegrass, clover, and dandelion in two- and three-species mixtures.

$F$ values and level of significances of the effects of sward composition (Sward), nitrogen fertilizer rates $(\mathrm{N})$, and year (Year) on sward characteristics.

Concentrations of $\mathrm{Ca}, \mathrm{Mg}, \mathrm{K}, \mathrm{P}$ and $\mathrm{Na}\left(\mathrm{g} \mathrm{kg}^{-1} \mathrm{DM}\right)$ in herbage of pure stand and mixtures of ryegrass $(\mathrm{G})$, white clover $(\mathrm{C})$, and dandelion (D) growing under two $\mathrm{N}$ levels ( 0 and $\left.200 \mathrm{~kg} \mathrm{ha}^{-1}\right)$, data are average of two years.

Concentrations of $\mathrm{Ca}, \mathrm{Mg}, \mathrm{K}, \mathrm{P}$ and $\mathrm{Na}$ in herbage required by high-producing dairy cows (600 kg cow; 301 milk day $^{-1}$ ) (after McKenzie and Jacobs, 2002). 


\section{LIST OF FIGURES}

Figure 2.1 The relationship between species richness and evenness and aboveground productivity in semi-natural grasslands at across-site level.

Figure 2.2 The relationship between community composition and aboveground productivity of the semi-natural grasslands at across-site level.

Figure 2.3 The relationship between plant diversity and grassland productivity (above- and below-ground) of the natural dry acidic grasslands at across-site level.

Figure 2.4 The relationship between community composition and productivity (above- and below-ground) of the natural dry acidic sandy grasslands at across-site level.

Figure 3.1 Annual herbage yield $\left(\mathrm{t} \mathrm{ha}^{-1}\right)$ of monocultures and mixtures of ryegrass $(\mathrm{G})$, white clover $(\mathrm{C})$, and dandelion (D) under two nitrogen fertilizer levels ( 0 and $200 \mathrm{~kg} \mathrm{~N} \mathrm{ha}^{-1}$ ) for three subsequent years.

Figure 3.2 Yield of the non-sown species ( $\mathrm{t}$ ha ${ }^{-1}$ ) of monocultures and mixtures of ryegrass $(\mathrm{G})$, white clover $(\mathrm{C})$, and dandelion (D) under two nitrogen fertilizer levels $\left(0\right.$ and $\left.200 \mathrm{~kg} \mathrm{~N} \mathrm{ha}^{-1}\right)$ for three subsequent years.

Figure 3.3 Nitrogen yield of monocultures and mixtures of ryegrass $(\mathrm{G})$, white clover (C), and dandelion (D) under two nitrogen fertilizer levels (0 and $200 \mathrm{~kg} \mathrm{~N} \mathrm{ha}^{-1}$ ) for three subsequent years.

Figure 3.4 Plot of relative yield (RY) of one species against RY of its companion species in the binary mixtures.

Figure 4.1 Mineral yield of $\mathbf{C a}\left(\mathrm{kg} \mathrm{ha}^{-1}\right)$ in herbage of pure stand and mixtures of ryegrass (G), white clover (C), and dandelion (D) growing under two $\mathrm{N}$ rates $\left(0\right.$ and $\left.200 \mathrm{~kg} \mathrm{ha}^{-1}\right)$ for two subsequent years.

Figure 4.2 Mineral yield of $\mathbf{M g}\left(\mathrm{kg} \mathrm{ha}^{-1}\right)$ in herbage of pure stand and mixtures of ryegrass $(\mathrm{G})$, white clover (C), and dandelion (D) growing under two $\mathrm{N}$ rates $\left(0\right.$ and $\left.200 \mathrm{~kg} \mathrm{ha}^{-1}\right)$ for two subsequent years 
Figure 4.3 Mineral yield of $\mathbf{K}\left(\mathrm{kg} \mathrm{ha}^{-1}\right)$ in herbage of pure stand and mixtures of ryegrass (G), white clover (C), and dandelion (D) growing under two $\mathrm{N}$ rates ( 0 and $\left.200 \mathrm{~kg} \mathrm{ha}^{-1}\right)$ for two subsequent years

Figure 4.4 Mineral yield of $\mathbf{P}\left(\mathrm{kg} \mathrm{ha}^{-1}\right)$ in herbage of pure stand and mixtures of ryegrass (G), white clover (C), and dandelion (D) growing under two $\mathrm{N}$ rates ( 0 and $\left.200 \mathrm{~kg} \mathrm{ha}^{-1}\right)$ for two subsequent years

Figure 4.5 Mineral yield of $\mathrm{Na}\left(\mathrm{kg} \mathrm{ha}^{-1}\right)$ in herbage of pure stand and mixtures of ryegrass $(\mathrm{G})$, white clover (C), and dandelion (D) growing under two $\mathrm{N}$ rates ( 0 and $\left.200 \mathrm{~kg} \mathrm{ha}^{-1}\right)$ for two subsequent years 


\section{Acknowledgements}

I would like to acknowledge all the people whose support gave me the possibility to undergo the work of this thesis.

First of all, I would like to express my gratitude to my Advisor Prof. Dr. Johannes Isselstein, Head of the Grassland Science Department, Georg August University, for acting as adviser and first referee of the $\mathrm{Ph}$. D. Work and for the special insights, guidance and help in making this work possible. His editorial advice was essential to the completion of this dissertation.

I am grateful to Prof. Dr. Wolfram Beyschlag, Head of the Experimental and Systems Ecology Department, Bielefeld University, for acting as co-adviser of the Ph. D. Work and for the support and encouragement in the course of the study. I am also thankful to Prof. Dr. Rolf Rauber, whose internal examination of the study added to the quality of the oral presentation.

My gratitude is extended to Dr. T. Steinlein and Dr. N. Wrage for their assistance and support, and S. Kesting for his invaluable help in plant identification. I also thank M. Seither and B. Hohlmann for their help in the field and C. Wunderow for her help on English editing. I want to send my thanks to M. Faramarzi and Dr. S. Unger for being nice officemates.

I am most grateful and thankful to the German Academic Exchange Program (DAAD) for making this work possible and for the financial support during the whole period of the $\mathrm{Ph}$. D. Work

I do not forget all my family, to whom I appreciate very much, my late mother, my father, my five sisters, and my brother. I cannot end without thanking my wife Enas, on whose constant encouragement and love I have relied throughout my work. 


\section{Summary}

Recently, several ecological experiments have shown that there is a positive relationship between plant diversity and ecosystem functions including productivity and nutrient retention. Most of these experiments were conducted on synthesized plant communities, where the applicability of their results to the permanent grasslands has been questioned. On the other hand, those studies suggested that increasing plant species diversity in pastures could also increase their productivity and enhance nutrient retention. To investigate the effect of plant diversity on productivity, two experiments have been conducted. The first experiments aimed to study the biodiversity-productivity relationship in permanent grasslands at within- and across-sites scale in semi-natural and natural dry acidic grasslands. The hypothesis tested was whether there is a consistent relationship between biodiversity and productivity or this relationship is influenced by the existing environmental conditions. The second experiment studied the effect of increasing the functional diversity of the ryegrass-white clover mixture by introducing a naturally growing forb (dandelion, Taraxacum officinale Web.) into the mixture under two nitrogen $(\mathrm{N})$ fertilization levels ( 0 and $\left.200 \mathrm{~kg} \mathrm{ha}^{-1}\right)$ on herbage yield, weed infestation and herbage mineral yields of $\mathrm{N}$, calcium $(\mathrm{Ca})$, magnesium $(\mathrm{Mg})$, potassium $(\mathrm{K})$, phosphorus $(\mathrm{P})$, and sodium $(\mathrm{Na})$.

In the first experiment, our results at within-site scale indicate that there is no general relationship between plant diversity and productivity that is consistent for all sites, therefore the type of the diversity-productivity relationship might be influenced by the existing environmental conditions. The relationship between diversity and productivity varied according to the used diversity measure. Productivity of the studied permanent grasslands is better explained by species evenness and plant community composition than by species richness. This confirms that complex measures of species diversity that combine several aspects of diversity such as species evenness, species identity as well as the interactions among the species may be better determinants of the response of the ecosystem to biodiversity. Our analysis at across-sites scale showed that the productivity of the seminatural grasslands is positively correlated with evenness, but no significant relationship between species richness and productivity was observed. In dry acidic grasslands, increasing species number was accompanied by higher productivity. This result can be explained by the fact that dry acidic grasslands are characterized by low species number and nutrient poor soils. Diversity (species richness) effects might be stronger in the low productive nutrient poor dry acidic grasslands than in semi-natural grasslands, as plant species from semi-natural 
grasslands could be functionally more redundant compared to plant species from the dry acidic grasslands.

In the second experiment, our results indicated that the herbage yield of the three-species mixture was not significantly different from the binary mixture of ryegrass and white clover but significantly higher than the monocultures and the other binary mixtures. This result can be explained by the low contribution of dandelion to the herbage yield of the three-species mixture, especially in the first year. Niche differentiation ( $\mathrm{RYT}>1$; relative yield total) among the sown species was more evident in the three-species mixture compared to the other mixtures. In respect to the yield stability of the sown pastures over years, our results gives an indication that the presence of dandelion in mixtures led to a better pasture stability across time, where the lower temperature and precipitations in the second and third years compared to the first year might be responsible for the reduction in herbage yields of ryegrass and white clover. The higher contribution of dandelion to the herbage yield in the second and third years partly compensated for the reduction in ryegrass and white clover yield as dandelion is better adapted to drought conditions. The biomass of the unsown species was significantly lower in the three-species mixture compared to white clover and dandelion monocultures as well as compared to ryegrass-dandelion and white clover-dandelion mixtures. This result shows that increasing plant diversity of the pastures might reduce weed invasion through complete exploitation of the available resources.

Regarding the mineral contents of the herbage, our results showed that dandelion contains the highest concentrations $\left(\mathrm{g} \mathrm{kg}^{-1} \mathrm{DM}\right)$ of $\mathrm{Mg}, \mathrm{K}$ and $\mathrm{P}$, followed by white clover and ryegrass, respectively. On the other hand, white clover monoculture produced the highest herbage mineral yield $\left(\mathrm{kg} \mathrm{ha}^{-1}\right)$ for the most tested minerals, followed by dandelion and ryegrass, respectively. This indicates the importance of white clover in pastures as a source of minerals for the animals and the companion crops in addition to the fact that dandelion herbage quality is higher than that of ryegrass. In the second year of the experiment, the three-species mixture produced significantly higher $\mathrm{Ca}$ and $\mathrm{Mg}$ yield compared to ryegrass-white clover mixture, which attributed to the fact that $\mathrm{Ca}$ and $\mathrm{Mg}$ contents of dandelion are higher than ryegrass. Generally, $\mathrm{Ca}$ yield was decreased in most mixtures by $\mathrm{N}$ application, while $\mathrm{Mg}, \mathrm{K}$, and $\mathrm{P}$ yields were significantly increased as a result of $\mathrm{N}$ application in mixtures that contain dandelion. 


\section{$1 \quad$ Introduction}

\subsection{Preface}

Biodiversity (biological diversity) is a complex topic, covering many aspects of biological variation and includes a wide spectrum of biotic scales from biotic community distribution on the planet to genetic variation within species. Biodiversity can be defined as "the full range of variety and variability within and among living organisms and the ecological complexes in of which they are part; it encompasses ecosystem or community diversity, species diversity, and genetic diversity (Noss, 1990). Biodiversity is generally represented in terms of numbers of entities (i.e. species richness), in addition to their distributions, functional traits and interactions. Generally, the term biodiversity is used as synonym for species richness (number of species); however, different components of biodiversity can also be described such as evenness, composition, and presence/ absence of key species.

At local and global scales, climatic changes and human activities caused dramatic changes in Earth's biodiversity through loss of species or invasion of exotic species. Changes in structure and composition of the biota might have a strong potential to affect adversely the functioning of the ecosystem and might cause reduction in goods and services provided to humanity.

Changes of managements of grasslands by using new forage species and cultivars and high rate of inputs caused changes in plant community composition. On the other hand, atmospheric $\mathrm{N}$ deposition may have similarly changed the species composition and diversity of grasslands in the last few decades (Smith et al., 1999).

Ecosystem functioning generally includes properties, goods and services of the ecosystems. The properties of the ecosystem refer to both the size of the components (materials such as organic matter) and the rate of the processes (e.g. energy flux). On the other hand, ecosystem services are those that have direct or indirect benefits to human such as maintaining hydrologic cycles, regulating climate, air and water purification, maintaining atmospheric composition, and recycling of nutrients. Ecosystem properties that have direct market value are referred to ecosystem goods and include for examples, food, medicines, genes, tourism and recreation. 
Recently, several experiments have shown that changes in plant species diversity affect several ecosystem functions, such as primary productivity, nutrient retention, ecosystem stability and vulnerability to invasion, as well as vegetation dynamics (Huston, 1997; Tilman et al., 1997; Hector et al., 1999; Loreau, 2000; Kahmen et al., 2005). Plant diversity and net primary productivity was found to be positively correlated in synthetic plant communities (Naeem et al., 1994; Tilman et al., 1996; Hector et al., 1999). Nutrient cycling was also found to be affected by plant diversity; higher plant nutrient uptake and lower leaching loss were found to be linked with increasing plant diversity (Hooper \& Vitousek, 1998). Complementarity in nutrient uptake and niche differentiation were supposed to explain such observations.

Invisibility of native plant communities by exotic species adversely affects ecosystem functioning and stability. Therefore the relationship between biodiversity and invisibility has recently attracted many ecological researches. Generally it has been found that increasing species richness decreases susceptibility to invasion by exotic species. It was also found that greater diversity causes greater ecosystem stability in response to disturbance and variations in environmental conditions. Stability can refer to the ability of an ecosystem function to persist at a given level over time. Stable ecosystem is resistant to disturbance and has higher resilience which means higher rate of recovery after disturbance.

The relationship between plant diversity and ecosystem functions is a topic that has been subjected to a hot debate in grassland ecology community because of the contradiction between the positive effects of the biodiversity which found in the synthesized plant community experiments (Naeem et al., 1994; Tilman et al., 1996; Hector et al., 1999) and results of the survey studies that investigated mature natural plant communities and found that biodiversity reaches the peak at the intermediate productivity level (Grime, 1973).

\subsection{Biodiversity measurements}

Plant species diversity can be defines as the number of species and their relative abundance in a defined area. The most widely used diversity measure is species richness (number of species). Relative abundance of species (evenness or equitability of species) is measured using a standardized index ( $\mathrm{J}$, an estimate of within community distribution of species), where its value ranging from 0 (high single species dominance) to 1 (equal abundance of all 
species). However, several diversity measures corporate both species richness and species evenness such as Shannon-Weiner and Simpson's diversity index (Magurran, 1988).

Species richness does not take into account species relative abundance and spatial scales; in addition, it gives overweight to rare species. Therefore, species richness as a sole measure of plant diversity could over- or underestimate the effect of biodiversity on ecosystem functions. Several investigations have found that evenness is more likely to be linked to how biodiversity affects ecosystem function (Stirling \& Wilsey, 2001; Wilsey \& Polley, 2002; Laird et al., 2003).

Recently, it is agreed that biodiversity includes, in addition to species richness, the composition of the genotypes, species, and functional types. Most experiments that investigate the effect of biodiversity on ecosystem functions have mainly used species richness as a sole measure of biodiversity, where other components of diversity have been underestimated, particularly functional diversity, which will emerge in the future as a very important aspect of biodiversity in respect to determining factors controlling ecosystem processes.

\subsection{Biodiversity-productivity relationship in natural plant communities}

Loss of species as a result of land management as well as other biotic and climatic factors could adversely affect human benefits from ecosystem functions, services and goods. Since a decade, the issue of whether plant diversity influences ecosystem processes such as primary productivity, nutrient retention, and ecosystem stability and vulnerability to invasion has received priority in ecological research (Husten, 1997; Tilman et al., 1997; Hector et al., 1999; Loreau, 2000; Kahmen et al., 2005). Among various ecosystem functions, productivity has taken much of the concern in the recent research due to its strong effect on the whole ecosystem.

There are two main hypotheses that explain the ecosystem response to species loss. The first one stated that species are primary singular, and species contribution to the ecosystem is unique and their loss causes detectable changes in ecosystem functioning (Loreau et al., 2002). The other hypothesis based on species functional redundancy and indicates that some species perform similar roles in communities and ecosystems, and may therefore be substitutable with little impact on ecosystem processes (Loreau et al., 2002). 
Most of the results regarding the relationship between species richness and ecosystem functioning were obtained from experiments that used synthesized plant communities. In these experiments, plant diversity has been artificially manipulated to construct the desired diversity levels by randomly drawing species from a limited species pool and growing them on bare soils (Symstad \& Tilman, 2001). Using this approach, it was concluded that the productivity of the ecosystem is asymptotically increased with increasing diversity (Naeem et al., 1994; Tilman et al., 1997; Hector et al., 1999). The proposed mechanisms behind this include (i) niche complementarity (spatially and temporally) that arises from the differences between species in resource requirements and leads to more complete resource use (Hooper, 1998); (2) facilitation that presents when an individual plant attains more biomass in the presence of interspecific neighbors (Tilman et al., 1996; Loreau \& Hector, 2001); (3) the insurance effect "where a highly diverse plant community is buffered from environmental extremes by having some species that are tolerant of different stresses" (McNaughton, 1977; Ives et al., 2000; Yachi \& Loreau, 2001); and (4) "sampling effect", that shows an increased probability of including a highly productive species or highly competitive one at the higher diversity levels (Huston, 1997).

The general results obtained by the experimental approach have been debated and it was argued that it has little predictive value to the relationship in the natural grasslands. it has been argued that the results of the synthesized plant community experiments have been driven mainly by the low diversity levels of few species-plots and by introducing highly productive or facilitative species (such as legumes) in the plots of high diversity level (Huston, 1997; Hooper \& Vitousek, 1998; Aarssen, 2001; Huston \& McBride, 2002). Other arguments include that their results might be short-lived transients that would be different when the interaction between species is allowed to reach equilibrium, in addition to the non-random extinction manner which is different from the extinction in the nature, and the sampling effect.

To overcome the above limitations, it has been suggested that there is a great need to use other approaches that is based on more "natural" ecosystems such as removal experiments and comparative studies (Chapin et al., 2000; Loreau et al., 2001; Kahmen et al., 2005). Recently several experiments have investigated this relationship in natural (i.e. not manipulated) plant communities, for example in semi-natural grasslands (e.g. Laird et al., 2003; Kahmen et al., 2005; Grace et al., 2007). Simi-natural grasslands represent all native herbaceous plant 
communities of grasses and forbs that have been subjected to agricultural practices without the regular use of inorganic fertilizers, herbicides or cultivation (Crofts \& Jefferson, 1994). However, studying diversity-productivity relationship in natural plant communities requires control on the large number of the interacting environmental factors, whish is practically impossible. Multivariate models have been used in an attempt to distinguish, statistically, the effect of environmental factors from those of biodiversity per se across sites of mature natural plant communities (Kahmen et al., 2005; Grace et al., 2007). Generally those experiments found that abiotic factors as well as community composition have a strong influence on the productivity of the semi-natural grasslands, but did not find strong effects of biodiversity per se represented by species number alone. However, these experiments suffered from the same limitations of the traditional observational approaches (surveys) as the productivity in different sites is controlled by the existing environmental conditions and by the present species pool within each site and that the effect of biodiversity could be easily masked by the overwhelming variation in abiotic factors.

\subsection{The relationship between biodiversity and productivity in ley system}

In recent years, management of pastures has been extended to include features that their ultimate objectives are not mainly the higher productivity of herbage yields. Management is optimized to enhance those functions of pastures which include sustainability, reduce chemical inputs, resistance to invasion, biodiversity of animals and the aesthetic value of the landscape (Spellerberg et al., 1991; Watkinson and Ormerod, 2001). Increasing species diversity and the functional traits that operate at ecosystem levels might enhance most if not all of the above mentioned functions of the managed pastures.

Early researches on forage production and pasture management have focused on monocultures of grasses that were optimized for high productivity or on simple binary mixtures of grasses and legumes (Blaser et al., 1952; Donald, 1963). More complex mixtures of grasses and legumes have been proven to have no success because of seedling competition and difficulties in management for the multi-species plant communities (Blaser et al., 1952).

In the last decade, many ecological researches that studied the effect of species richness on ecosystem productivity in synthetic plant communities (Naeem et al., 1994; Tilman et al., 1996; Hector et al., 1999) indicated that primary productivity is positively correlated with species richness. Those studies suggested that increasing plant species diversity in pastures 
could also increase herbage yield, enhance nutrient retention and reduce loss of nutrients, especially nitrogen, into the environment, reduce invisibility by alien plants and increase yield stability (Sanderson et al., 2004). It has been suggested to apply the results and the concepts of these experiments in forage and pasturelands (Brummer, 1998), for livestock production (Tilman et al., 1999), and agricultural management (Minns et al., 2001).

In temperate climates, perennial ryegrass (Lolium perenne L.) and white clover (Trifolium repens L.) are the dominant constituents of cultivated pastures throughout the world. Increasing the number of sown species of the grass/ legume mixtures is a common practice in temperate grassland farming (Sanderson et al., 2004), but most of the introduced species are belonging to the grass family, where forbs are hardly considered in this respect (Sheldrick, 2000). Increasing the functional diversity of the grown species in grasslands might enhance swards performance through complementarity and niche differentiation. Seasonal and spatial complementarity among functional groups and dominance of different resources by different groups are also suggested means by which different species composition affects the efficiency of resource use (Vitousek \& Walker, 1989; Wedin \& Tilman, 1990; Chapin et al., 1995).

\subsection{Objectives and hypotheses}

\section{Natural and semi-natural grasslands}

To study the diversity-productivity relationship in natural or semi-natural ecosystems, two important properties should be present. First, the relationship should be studied when all factors other than biodiversity are held constant (this property was only applied to the experimental approach) while the second property should be that the biodiversity levels are not manipulated (this was only a characteristic of the observational approach). Combining both characteristics together has not been done so far, up to our knowledge, in any empirical study.

In our approach to study this relationship in natural plant communities (which is presented in chapter two of the current thesis), we combined these properties in one experiment. We studied the relationship between plant diversity and productivity in semi-natural and natural grasslands at within-site scale (between plots within a site) which would minimize the confounding effect of environmental factors. Doing so will enable us to test the hypothesis whether diversity-productivity relationship is a site dependant relationship (depends on the 
existing environmental condition and species pool) or a general pattern can be observed (Chapter 2).

\section{Ley system}

One of the most widespread grassland species in Europe is dandelion (Taraxacum officinale Weber). This species colonizes numerous different habitats, grows in a diversity of soil types, resists drought and adapts to a wide range of light and shade intensities (Abu-Dieyeh \& Watson, 2007). In the present research (chapter three and four) the forage potential of dandelion is investigated for the first time as a constituent of seed mixtures with ryegrass and white clover. A field experiment was set up with monocultures and mixtures of the respective species in a replacement series where competition and complementary effects of species in the mixtures could be separated. The main hypothesis that was that adding dandelion to ryegrasswhite clover mixtures would improve its performance.

In chapter three, the effect dandelion on the agronomic performance of perennial ryegrasswhite clover mixtures in terms of herbage yield, nitrogen retention, and weed invasion is investigated. While in chapter four, we investigated the effect of dandelion on herbage yield of $\mathrm{Ca}, \mathrm{Mg}, \mathrm{K}, \mathrm{P}$, and $\mathrm{Na}$ of the swards. 


\section{The relationship between plant diversity and productivity of natural and semi- natural grasslands}

\section{$2.1 \quad$ Abstract}

Despite the fact that several experiments have been conducted to explore the biodiversityproductivity relationship in synthesized and natural plant communities, the results obtained were contradictory and no clear consensus has been reached. Recent experiments that surveyed mature natural plant communities have investigated the biodiversity-productivity relationship across environmental gradients, where biotic and/or abiotic factors are correlated with the observed diversity and productivity levels. We studied the effect of plant diversity on ecosystem productivity in semi-natural (i.e. managed at a low intensity with moderate level of disturbance) and natural (i.e. not managed) dry acidic grasslands at a within-site scale in order to minimize the confounding effect of environmental factors. We tested the effects of various diversity measures (species richness and species evenness) and plant community composition on productivity within- and across-sites scale. Furthermore, we tested the hypothesis that there would be a single general relationship between diversity and productivity. The relationship between diversity and productivity varied according to the used diversity measure. Species richness only poorly explained the variation in productivity within natural and semi-natural communities. The Results indicate that variations in system productivity are better explained by species evenness and plant community composition than by species richness. This confirms that complex measures of species diversity that combine several aspects of diversity such as species evenness, species identity as well as the interactions among the species may be better determinants of the response of the ecosystem to biodiversity. Based on our analysis at within-site scale, we come to the conclusion that there is no general relationship between plant diversity and productivity that is consistent for all sites and that the type of the diversity-productivity relationship is influenced by the existing environmental conditions.

\subsection{Introduction}

In the past decade, the effect of species loss on ecosystem functioning such as primary productivity, nutrient relations, ecosystem stability and vulnerability to invasion, as well as vegetation dynamics has received priority in ecological research (Huston, 1997; Tilman, 
Lehman \& Thomson, 1997; Hector et al., 1999; Loreau, 2000; Kahmen et al., 2005). In spite of the fact that a large number of experiments have been conducted to investigate the diversity-productivity relationship, the results obtained were contradictory (Schmid 2002; Hector et al., 2007) and a common theory was not developed so far.

Generally, two approaches have been used to study the relationship between species richness and ecosystem functioning; the experimental and the observational approach. In the first approach, plant diversity was artificially manipulated to construct the desired diversity levels by randomly drawing species from a limited species pool and growing them on bare soils (Symstad \& Tilman, 2001), where the desired diversity levels were maintained for several years by weeding. In the observational approach, plant diversity and composition were not manipulated; instead comparative studies were conducted in natural (i.e. not managed) or semi-natural (i.e. managed at a low intensity with a moderate level of disturbance) grasslands to relate the differences in diversity to the observed productivity along different sites and environmental gradients (Kahmen et al., 2005; Grace et al., 2007).

Using the experimental approach, it was concluded that the productivity of the ecosystem increases asymptotically with increasing diversity (Naeem et al., 1994; Tilman et al., 1997; Hector et al., 1999). This result has been attributed mainly to niche complementarity and facilitation among species (Hooper, 1998; Tilman et al., 1996; Loreau \& Hector, 2001), as well as to the "sampling effect", i.e. an increased probability of including a highly productive or highly competitive species at the higher diversity levels (Huston, 1997; Huston et al., 2000). In natural and semi-natural grasslands, most observational studies show that biodiversity reaches a peak at intermediate productivity levels, where high or lowproductivity occurs with low diversity levels. This is best described by the "hump-backed" model (Grime, 1973). This model indicates that species richness declines in more productive sites due to higher rates of extinction of less competitive species as a result of higher dominance of strong competitors (e.g. Laird et al., 2003; Kahmen et al., 2005; Grace et al., 2007).

The observational approach studies the effect of species diversity on productivity across environmental gradients, where other factors such as soil fertility, climate, disturbance regime, or herbivory are correlated with the observed diversity and productivity levels (Kahmen et al., 2005). Recent experiments that based on natural ecosystems (species richness 
is not manipulated) have distinguished between environmental and biodiversity effects across a range of semi-natural grasslands by employing a multivariate statistical analysis (Kahmen et al., 2005; Grace et al., 2007). Generally, a strong effect of species richness on productivity was not evident in these experiments. This might be explained by the overwhelming effects of environmental factors which might have masked the diversity effect (Diaz \& Cabido, 2001; Schmid, 2002; Hector et al., 2007).

In most experiments, diversity has often been measured as species number where other diversity components have received little attention. Recently, there are accumulating evidences that the effect of diversity is mainly due to species composition and the interaction between species rather than to be attributed solely to species number (Crawley, et al., 1999; Tilman, 1999; Laird et al., 2003; Kahmen et al., 2005). Although it is agreed that biodiversity includes both species richness and species composition, very little work has been done to address the effect of different biodiversity measures nor to investigate which one is related to ecosystem functioning more closely (Diaz \& Cabido, 2001; Hooper et al., 2005).

New approaches that based on more "natural" ecosystems are needed to overcome the above mentioned limitations (Chapin et al., 2000; Loreau et al., 2001; Kahmen et al., 2005). In this kind of approach, biotic and/or abiotic factors should not be correlated with the diversity and productivity levels and the biodiversity levels should not be manipulated. To our knowledge, this has not been done empirically in one study, yet.

The present experiment was designed to investigate whether a general diversity-productivity relationship can be found in natural ecosystems (i.e. species are not manipulated) or whether this relationship is varied according to the existing biotic and abiotic conditions. Therefore, we have chosen two different grasslands, species rich, semi-natural grasslands (managed through cutting and/or aftermath grazing with 9-17 species $\mathrm{m}^{-2}$ ) and dry acidic natural grasslands (not managed, nutrients poor with $1-5$ species $0.25 \mathrm{~m}^{-2}$ ).

We investigated the effect of diversity on productivity at within-site scale (i.e. among plots within a site) to reduce the confounding effect of environment with diversity which is typical for the observational approach. We studied the effect of various components of biodiversity including species number, evenness, and community composition on the productivity of natural and managed semi-natural grasslands in order to test whether different diversity 
components would have different relationships with ecosystem productivity. The main hypothesis was that there is a general relationship between diversity and productivity and that this relationship is not affected by the existing environmental conditions.

\subsection{Materials and methods}

\section{Study sites}

The study sites were chosen from two different grassland types, semi-natural and natural dry acidic grasslands. Data from the semi-natural grasslands were collected in 2005, while the data collection from the natural dry grasslands took place in 2006.

In 2005, seven sites (M1-M7), each measuring 30x30 $\mathrm{m}^{2}$ and differing in plant community composition, productivity level, and soil characteristics (see Table 2.1) were established in managed semi-natural grasslands near Goettingen, central Germany $\left(51^{\circ} 31^{\prime} \mathrm{N}, 9^{\circ} 55^{\prime} \mathrm{E}\right)$. The sites had not received any mineral fertilizer application, tillage or re-sowing for at least the last decade. The sites were subjected to one or two cuts hay meadows with sometimes aftermath grazing.

In 2006, another three sites (D1-D3) each measuring 10x10 $\mathrm{m}^{2}$ were chosen from a natural dry acidic grassland area located near Fuerth, southern Germany $\left(49^{\circ} 26^{\prime} \mathrm{N}, 10^{\circ} 50^{\prime} \mathrm{E}\right)$, representing early stages of succession (Table 2.2).

\section{Data collection}

In 2005 , in the semi-natural grasslands 18 one square meter quadrates were established within each site, which were then used as the experimental units for the diversity- productivity relationship analysis. Each site was divided into three blocks, in each block six quadrates were established, the quadrates were fixed systematically along the block (beginning, middle and the end of the block). For each quadrate, all occurring plant species were recorded and the proportion of each species from the total dry weight biomass was visually estimated following a method of percentage ranking (Whalley \& Hardy, 2000). Above-ground biomass (thereafter above-ground productivity) was measured for each quadrate by harvesting all plant material $(>2 \mathrm{~cm})$. The harvest took place when the swards reached the maximum yield (at peak standing crop point). The sampling period lasted from beginning of June to mid July. Before harvesting, the yield was recorded periodically using the rising plate meter method to determine peak standing crop (Correll et al., 2003). This is a nondestructive method which 
can be used repeatedly on the same plot to estimate the herbage yield. Below-ground biomass (below-ground productivity) was measured for three sites; M1, M2 and M3 by taking a soil cylinder $(10 \mathrm{~cm}$ diameter $\times 20 \mathrm{~cm}$ depth) at the center of each quadrate. Root samples were then washed with running tap water over a sieve (1 mm mesh size), cleaned manually with forceps and collected on aluminum trays. All harvested plant material was oven dried $\left(103^{\circ} \mathrm{C}\right)$ and weighed. Nine soil samples $(0-10 \mathrm{~cm}$ depth) were taken from each site for the analysis of $\mathrm{pH}$ and exchangeable phosphorus and potassium (calcium ammonium acetate extraction) (Table 2.1).

In the dry acidic natural grassland, 15 quadrates of $0.25 \mathrm{~m}^{2}$ were established randomly at each of the three sites. The same measurements as described for the semi-natural grassland were carried out in these quadrates, except that Braun-Blanquet classes were used to estimate species canopy cover instead of the estimation of dry biomass proportion for each species and that the root biomass for each quadrate was harvested totally (by excavating all root materials in the upper $20 \mathrm{~cm}$ ) rather than taking soil cylinders as done in semi natural grassland plots. Nine soil samples $(0-10 \mathrm{~cm}$ depth) were taken from each site to be analyzed for $\mathrm{pH}$ and mineral nitrogen $(\mathrm{N})$ concentration (Continuous-flow Analyzer, FIALAB, Medizin- und Labortechnik Engineering GmbH, Dresden), because $\mathrm{N}$ and $\mathrm{pH}$ are considered to be the main soil factors that affect plant composition and productivity in these nutrients-poor dry acidic grasslands (Table 2.2). However, mineral $\mathrm{N}$ was not analyzed in the semi-natural grasslands, as we believed that, at within-site scale, variations in mineral $\mathrm{N}$ concentration in the soil would have little effect on species composition and productivity. Mostly, in semi-natural grasslands, $\mathrm{N}$ is found in organic forms, where the concentration of mineral $\mathrm{N}$ is highly fluctuated over time.

\section{Data analysis}

The diversity-productivity relationship was analyzed at two levels; within-site level (data from one site) and across-sites level (data from all sites within each grassland type).

\section{Diversity and community composition analysis}

Diversity measures included species richness (S) and species evenness (J') (Ma, 2005). Species richness was determined as the total number of species present in a quadrate. Species evenness was obtained using the following equation:

$\mathrm{J}^{\prime}=\mathrm{D}^{\prime} / \mathrm{D}_{\max }$, 
where $\mathrm{D}_{\max }=\mathrm{S}$

and $\mathrm{D}^{\prime}=1 / \sum\left(\mathrm{P}_{\mathrm{s}}^{2}\right)$, where $\mathrm{Ps}$ is species proportion.

Species composition of the sampled vegetation (quadrates) was analyzed using non-metric multidimensional scaling (NMDS) by using the CAP 3.0 version (Community Analysis Package 2004). NMDS is a technique to express the similarity between different objects in a small number of dimensions. The method attempts to place the most similar samples closest together (Kenkel \& Orloci, 1986). The starting point for the calculations was the dissimilarity matrix between all the quadrates. For the dissimilarity matrix, the Bray-Curtis coefficient was used (Faith, Minchin, \& Belbin, 1987). NMDS ordination was based on square-roottransformed species data. The scores of the NMDS' first two axes were used as variables that represent the plant community composition.

Table 2.1 Species and soil characteristic (average of 18 quadrates) of the semi-natural grasslands.

\begin{tabular}{|c|c|c|c|c|c|c|}
\hline Site & Dominant species & $\begin{array}{l}\text { Avg. \& } \\
\text { range of } \\
\text { species } \\
\text { number } \mathrm{m}^{-2}\end{array}$ & $\begin{array}{l}\text { Avg. \& range } \\
\text { of above-ground } \\
\text { Biomass (g DM } \\
\mathrm{m}^{-2} \text { ) }\end{array}$ & $\mathrm{pH}$ & $\begin{array}{l}\mathrm{P}^{\mathrm{b}} \\
\left(\mathrm{mg} \mathrm{g}^{-1}\right)\end{array}$ & $\begin{array}{l}\mathrm{K} \\
\left(\mathrm{mg} \mathrm{g}^{-1}\right)\end{array}$ \\
\hline M1 & $\begin{array}{l}\text { Arrhenatherum elatius } \\
\text { Festuca rubra }\end{array}$ & $\begin{array}{l}9.7 \\
(8-13)\end{array}$ & $\begin{array}{l}536 \\
(420-651)\end{array}$ & $\begin{array}{l}6.64 \\
(0.13)^{\mathrm{a}}\end{array}$ & $\begin{array}{l}0.13 \\
(0.02)\end{array}$ & $\begin{array}{l}0.21 \\
(0.05)\end{array}$ \\
\hline M2 & $\begin{array}{l}\text { Festuca rubra } \\
\text { Agrostis stolonifera }\end{array}$ & $\begin{array}{l}17.9 \\
(14-23)\end{array}$ & $\begin{array}{l}576 \\
(377-749)\end{array}$ & $\begin{array}{l}6.03 \\
(0.33)\end{array}$ & $\begin{array}{l}0.06 \\
(0.02)\end{array}$ & $\begin{array}{l}0.11 \\
(0.03)\end{array}$ \\
\hline M3 & $\begin{array}{l}\text { Arrhenatherum elatius } \\
\text { Rhinantus angustifolia }\end{array}$ & $\begin{array}{l}16.6 \\
(11-22)\end{array}$ & $\begin{array}{l}409 \\
(284-507)\end{array}$ & $\begin{array}{l}6.04 \\
(0.34)\end{array}$ & $\begin{array}{l}0.07 \\
(0.02)\end{array}$ & $\begin{array}{l}0.05 \\
(0.03)\end{array}$ \\
\hline M4 & $\begin{array}{l}\text { Alepocurus pratensis } \\
\text { Dactylis glomerata }\end{array}$ & $\begin{array}{l}12 \\
(6-16)\end{array}$ & $\begin{array}{l}392 \\
(328-506)\end{array}$ & $\begin{array}{l}6.48 \\
(0.26)\end{array}$ & $\begin{array}{l}0.06 \\
(0.02)\end{array}$ & $\begin{array}{l}0.21 \\
(0.05)\end{array}$ \\
\hline M5 & $\begin{array}{l}\text { Elymus repens } \\
\text { Ranunculus repens }\end{array}$ & $\begin{array}{l}11 \\
(7-15)\end{array}$ & $\begin{array}{l}562 \\
(415-687)\end{array}$ & $\begin{array}{l}6.39 \\
(0.33)\end{array}$ & $\begin{array}{l}0.07 \\
(0.04)\end{array}$ & $\begin{array}{l}0.22 \\
(0.07)\end{array}$ \\
\hline M6 & $\begin{array}{l}\text { Festuca rubra } \\
\text { Holcus lanatus }\end{array}$ & $\begin{array}{l}10.6 \\
(6-16)\end{array}$ & $\begin{array}{l}406 \\
(296-621)\end{array}$ & $\begin{array}{l}5.66 \\
(0.63)\end{array}$ & $\begin{array}{l}0.04 \\
(0.02)\end{array}$ & $\begin{array}{l}0.14 \\
(0.08)\end{array}$ \\
\hline M7 & $\begin{array}{l}\text { Lolium perenne } \\
\text { Trifolium repens }\end{array}$ & $\begin{array}{l}13.4 \\
(10-19)\end{array}$ & $\begin{array}{l}445 \\
(303-582)\end{array}$ & $\begin{array}{l}6.18 \\
(0.42)\end{array}$ & $\begin{array}{l}0.02 \\
(0.01)\end{array}$ & $\begin{array}{l}0.09 \\
(0.03)\end{array}$ \\
\hline
\end{tabular}


Table 2.2 Species and soil characteristics (average of nine samples) of the natural grasslands.

\begin{tabular}{|c|c|c|c|c|c|c|}
\hline Site & Dominant species & $\begin{array}{l}\text { Avg. } \\
\text { and } \\
\text { range of } \\
\text { species } \\
\text { number/ } \\
0.25 \mathrm{~m}^{2}\end{array}$ & $\begin{array}{l}\text { Avg. and } \\
\text { range of } \\
\text { above- } \\
\text { ground } \\
\text { Biomass } \\
(\mathrm{g} \mathrm{DM} \\
0.25 \mathrm{~m}^{-2} \text { ) }\end{array}$ & $\mathrm{pH}$ & $\begin{array}{l}\mathrm{NH}_{4} \\
\left(10^{-3}\right) \\
\mathrm{g} \mathrm{kg}^{-1}\end{array}$ & $\begin{array}{l}\mathrm{NO}_{3} \\
\left(10^{-3}\right) \\
\mathrm{g} \mathrm{kg}^{-1}\end{array}$ \\
\hline D1 & $\begin{array}{l}\text { Corynephorus canescens } \\
\text { Rumex acetosella }\end{array}$ & $\begin{array}{l}2.5 \\
(1-4)\end{array}$ & $\begin{array}{l}12.2 \\
(3.4-38.6)\end{array}$ & $\begin{array}{l}5.89 \\
(0.42)^{\mathrm{a}}\end{array}$ & $\begin{array}{l}0.20 \\
(0.14)\end{array}$ & $\begin{array}{l}0.83 \\
(0.41)\end{array}$ \\
\hline D2 & $\begin{array}{l}\text { Corynephorus canescens } \\
\text { Rumex acetosella }\end{array}$ & $\begin{array}{l}2.0 \\
(1-4)\end{array}$ & $\begin{array}{l}15.3 \\
(2.3-35.6)\end{array}$ & $\begin{array}{l}4.39 \\
(0.12)\end{array}$ & $\begin{array}{l}0.30 \\
(0.25)\end{array}$ & $\begin{array}{l}0.97 \\
(0.48)\end{array}$ \\
\hline D3 & $\begin{array}{l}\text { Corynephorus canescens } \\
\text { Rumex acetosella }\end{array}$ & $\begin{array}{l}3.8 \\
(2-5)\end{array}$ & $\begin{array}{l}22.8 \\
(10.2- \\
35.3)\end{array}$ & $\begin{array}{l}5.52 \\
(0.76)\end{array}$ & $\begin{array}{l}0.16 \\
(0.03)\end{array}$ & $\begin{array}{l}1.81 \\
(0.87)\end{array}$ \\
\hline
\end{tabular}

\section{Statistical analysis}

Least squares simple linear regressions were used to analyze the relationship between plant diversity (species richness and evenness) and productivity, while the relationship with the highest $\mathrm{R}^{2}$ and the lowest $\mathrm{p}$ value was chosen for the regression analysis between community compositions (scores of NMDS axes) and productivity. Assumptions of the regression models were tested by graphical and numerical methods as Q-Q plot and Kolmogorov-Smirnov test for normality of residuals and scatter diagrams of residuals and predicted values for the constancy of variance. Statistical analyses were performed using SPSS version 12.0 (SPSS 2001).

\section{$2.4 \quad$ Results}

\section{Within-site level}

In the semi-natural grasslands, the relationship between species richness and above-ground productivity was significant for two sites (M5 and M6) with a negative correlation. Evenness was positively correlated with above-ground productivity for two sites (M1, M2; Table 2.3), as above-ground productivity increased along with increasing evenness. The results presented show that the relationship between diversity and below-ground productivity was rather weak as only one site $(\mathrm{M} 1)$ showed a significant correlation $\left(\mathrm{R}^{2}=0.23, \mathrm{P}<0.1\right)$ between evenness and below-ground biomass (Table 2.4). In the natural dry acidic grasslands, no significant 
relationship between species richness and evenness and above-ground productivity was found (Table 2.3).

In the semi-natural grasslands, five sites (M1, M2, M5, M6, and M7) showed a significant relationship between community composition and above-ground productivity for at least one NMDS axis (Table 2.3). In general, community composition explains variations in aboveground productivity better than species richness and evenness. Regarding the relationship between community composition and below-ground productivity (Table 2.4), four sites showed significant relationships. Plant community compositions explained $27 \%$ of variation in below-ground productivity in the first site $(\mathrm{P}<0.05)$.

In the natural dry acidic grasslands, community composition had no significant effect on above-ground productivity. In addition, the relationship between composition and belowground productivity was more obvious than for above-ground productivity, as the three sites showed a significant relationship between community composition and below-ground productivity (Tables $2.3 \& 2.4$ ).

Table $2.3 \mathrm{R}^{2}$ of the relationship between plant diversity and above-ground productivity in semi natural and natural dry acidic grasslands, within-site level.

\begin{tabular}{|c|c|c|c|c|}
\hline \multirow{2}{*}{ Site Diversity } & \multirow{2}{*}{$\begin{array}{l}\text { Species } \\
\text { number }\end{array}$} & \multirow{2}{*}{ Evenness } & \multicolumn{2}{|c|}{ Species composition } \\
\hline & & & NMDS 1 & NMDS 2 \\
\hline \multicolumn{5}{|l|}{ Semi-Natural } \\
\hline M1 & $0.00^{\text {ns a }}$ & $0.19^{+}$ & $0.47^{+} \mathrm{C}$ & $0.00^{\mathrm{ns}}$ \\
\hline M2 & $0.07^{\mathrm{ns}}$ & $0.25^{*}$ & $0.58^{* *} \mathrm{~L}$ & $0.01^{\mathrm{ns}}$ \\
\hline M3 & $0.00^{\mathrm{ns}}$ & $0.04^{\mathrm{ns}}$ & $0.00^{\mathrm{ns}}$ & $0.10^{\mathrm{ns}}$ \\
\hline M4 & $0.01^{\mathrm{ns}}$ & $0.11^{\mathrm{ns}}$ & $0.03^{\mathrm{ns}}$ & $0.08^{\mathrm{ns}}$ \\
\hline M5 & $0.37^{* *}$ & $0.04^{\mathrm{ns}}$ & $0.19^{+} \mathrm{L}$ & $0.05^{\mathrm{ns}}$ \\
\hline M6 & $0.19^{+}$ & $0.00^{\mathrm{ns}}$ & $0.40^{*} \mathrm{Q}$ & $0.31^{*} \mathrm{~L}$ \\
\hline M7 & $0.00^{\mathrm{ns}}$ & $0.00^{\mathrm{ns}}$ & $0.41^{+} \mathrm{C}$ & $0.30 * \mathrm{~ns}$ \\
\hline \multicolumn{5}{|l|}{ Natural } \\
\hline D1 & $0.05^{\mathrm{ns}}$ & $0.04^{\mathrm{ns}}$ & $0.02^{\mathrm{ns}}$ & $0.01^{\mathrm{ns}}$ \\
\hline D2 & $0.10^{\mathrm{ns}}$ & $0.05^{\mathrm{ns}}$ & $0.04^{\mathrm{ns}}$ & $0.10^{\mathrm{ns}}$ \\
\hline D3 & $0.02^{\mathrm{ns}}$ & $0.11^{\mathrm{ns}}$ & $0.05^{\mathrm{ns}}$ & $0.07^{\mathrm{ns}}$ \\
\hline
\end{tabular}


Table $2.4 \mathrm{R}^{2}$ of the relationship between plant diversity and below-ground productivity in semi natural and natural dry acidic grasslands, within-site level.

\begin{tabular}{|c|c|c|c|c|}
\hline \multirow{2}{*}{ Site Diversity } & \multirow{2}{*}{$\begin{array}{l}\text { Species } \\
\text { number }\end{array}$} & \multirow{2}{*}{ Evenness } & \multicolumn{2}{|c|}{ Species composition } \\
\hline & & & NMDS 1 & NMDS 2 \\
\hline \multicolumn{5}{|l|}{ Semi-Natural } \\
\hline M1 & $0.0^{\mathrm{ns} \mathrm{a}}$ & $0.23^{+}$ & $0.27^{*} \mathrm{~L}$ & $0.01^{\mathrm{ns}}$ \\
\hline M2 & $0.06^{\mathrm{ns}}$ & $0.12^{\mathrm{ns}}$ & $0.01^{\mathrm{ns}}$ & $0.08^{\mathrm{ns}}$ \\
\hline M3 & $0.0^{\mathrm{ns}}$ & $0.0^{\mathrm{ns}}$ & $0.0^{\mathrm{ns}}$ & $0.0^{\mathrm{ns}}$ \\
\hline \multicolumn{5}{|l|}{ Natural } \\
\hline D1 & $0.18^{\mathrm{ns}}$ & $0.11^{\mathrm{ns}}$ & $0.40^{*} \mathrm{~L}$ & $0.06^{\mathrm{ns}}$ \\
\hline D2 & $0.10^{\mathrm{ns}}$ & $0.04^{\mathrm{ns}}$ & $0.01^{\mathrm{ns}}$ & $0.30^{*} \mathrm{~L}$ \\
\hline D3 & $0.00^{\mathrm{ns}}$ & $0.06^{\mathrm{ns}}$ & $0.09^{\mathrm{ns}}$ & $0.22^{+} \mathrm{L}$ \\
\hline
\end{tabular}

\section{Across-sites level}

The across-sites relationship between plant diversity and productivity in the semi-natural grasslands is presented in figure (2.1). Evenness seems to be more important in explaining the variation in above- and below-ground productivity than species richness. Across all seminatural sites, productivity increased linearly with increasing evenness $\left(\mathrm{R}^{2}=0.14\right.$ and $0.11, \mathrm{P}<$ 0.001 and 0.016 for above- and below-ground productivity, respectively). However, there was no significant relationship between species number and productivity (Figure 2.1).

In the natural dry acidic sites (Figure 2.3), ecosystem productivity (both above- and belowground) increased linearly with increasing species richness. No such effect was found for the relationship between productivity and evenness.

In the semi-natural grasslands (Figure 2.2), the relationship between community composition and above-ground productivity was significant for NMDS1 and NMDS2 $\left(\mathrm{R}^{2}=0.06\right.$ and 0.07; $\mathrm{P}=0.03$ and 0.009 , respectively), though only a small part of the total variation of productivity is explained by community composition. But no significant relationship between community composition and below-ground productivity was found (data not shown).

Similar results have been obtained from the natural dry acidic grasslands (Figure 2.4), where above- and below-ground productivity were significantly correlated with plant community 
composition, with the relationship being stronger for the below- than for the above-ground productivity. Community composition explained $17 \%$ and $22 \%$ of the variation in belowground productivity compared to only $11 \%$ and none of the variation in above-ground productivity for NMDS1 and NMDS2, respectively.

Above-ground
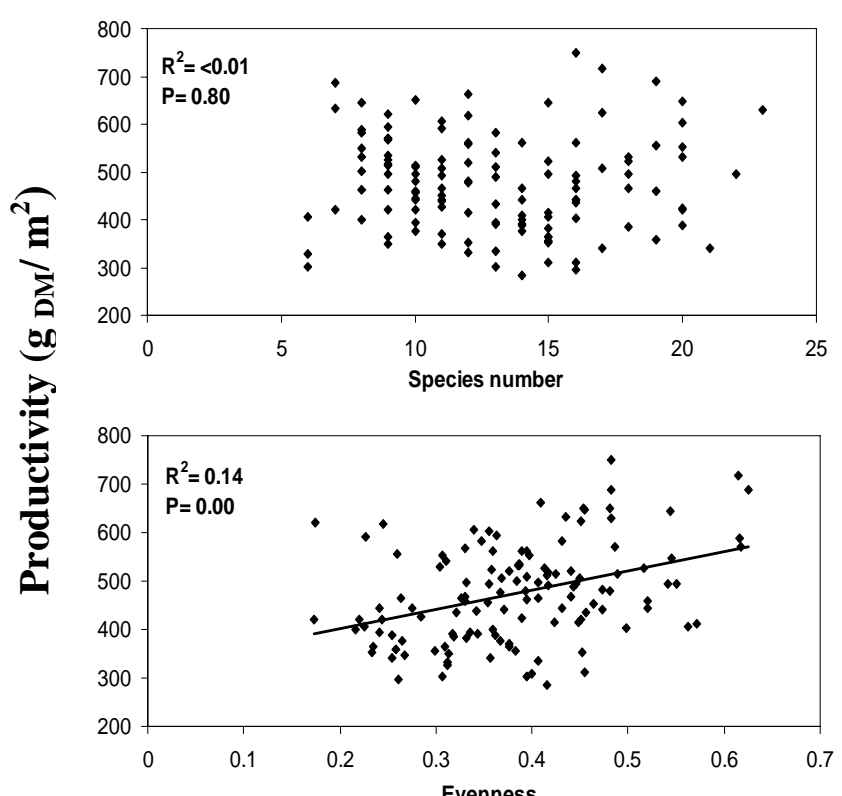

Below-ground
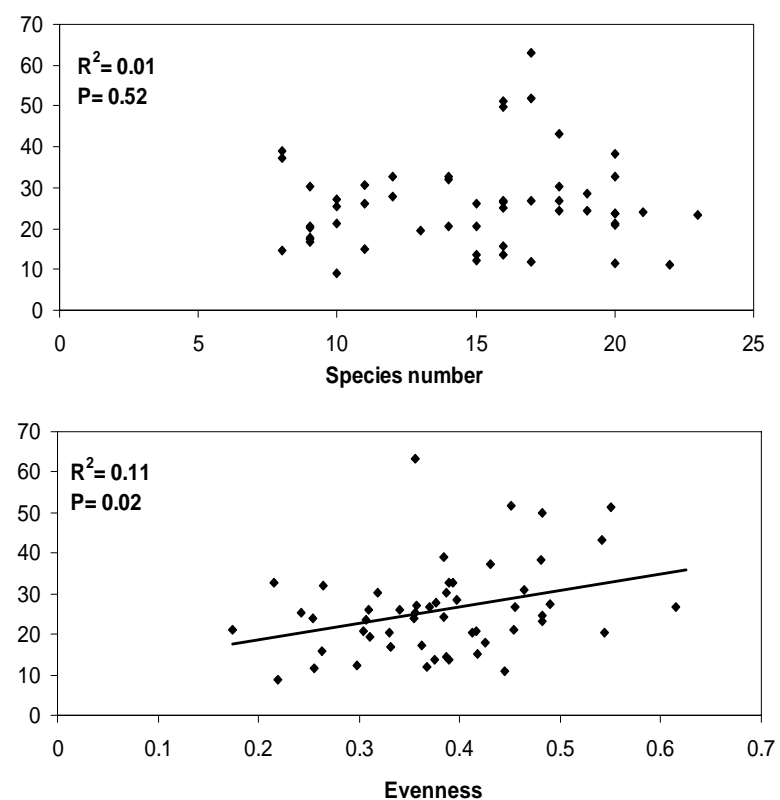

Fig. 2.1 The relationship between species richness and evenness and above-ground productivity in semi-natural grasslands at across-site level.
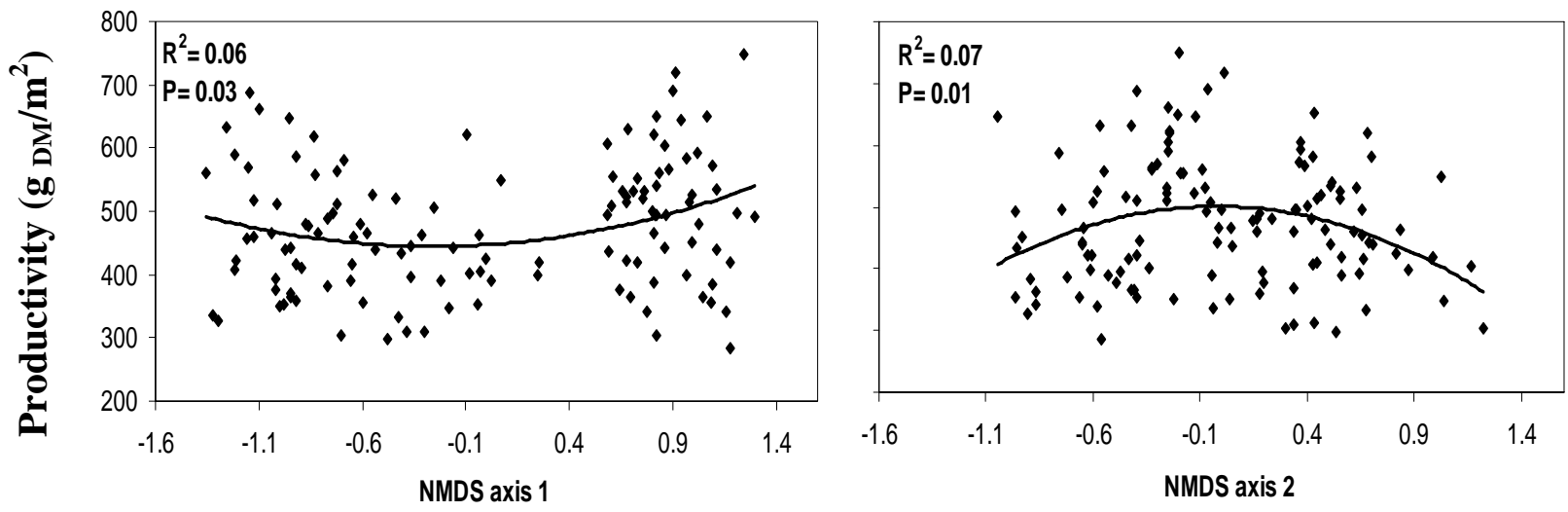

Figure 2.2 The relationship between community composition and above-ground productivity of the semi-natural grasslands at across-site level 
Above-ground

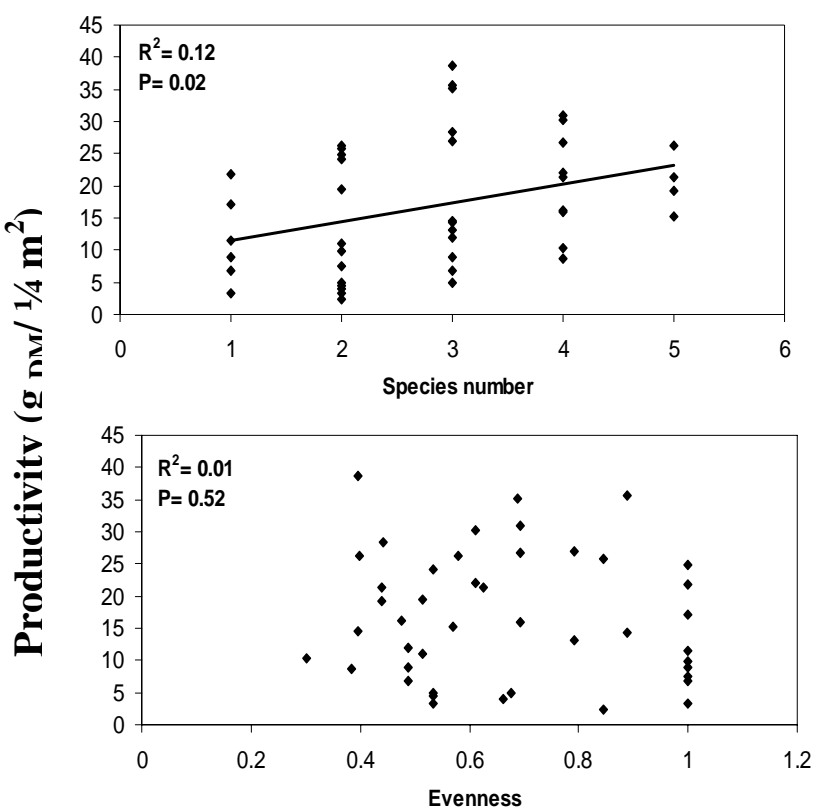

Below-ground
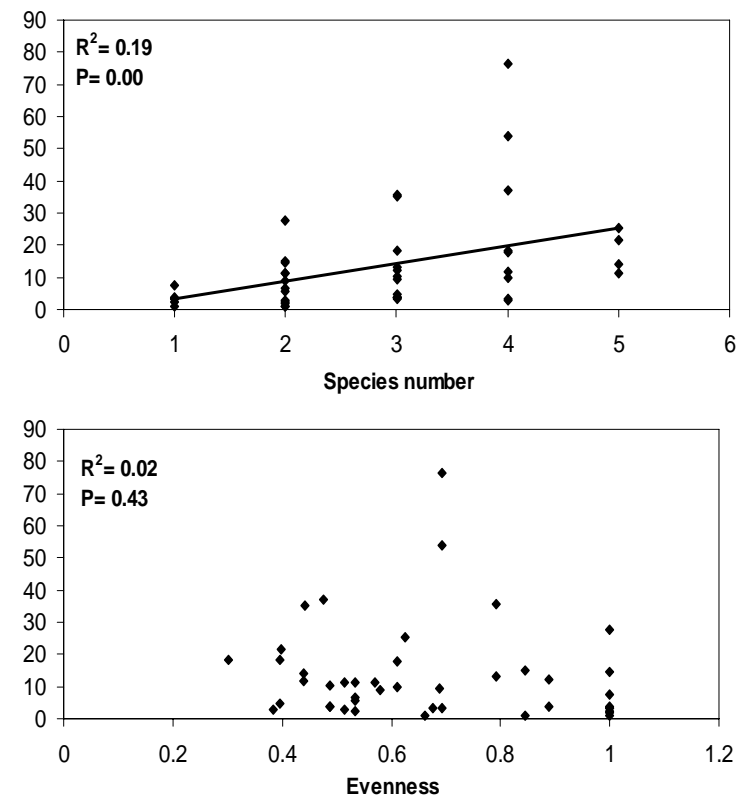

Figure 2.3 The relationship between plant diversity and grassland productivity (above- and below-ground) of the natural dry acidic grasslands at across-site level.

Above-ground
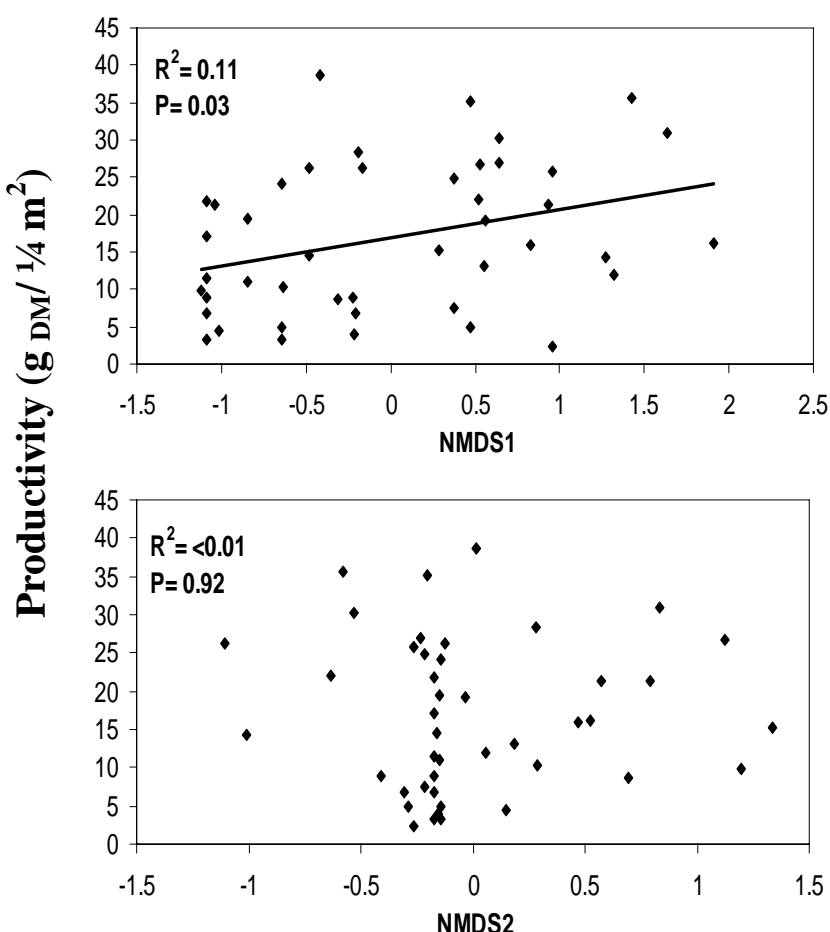

Below-ground
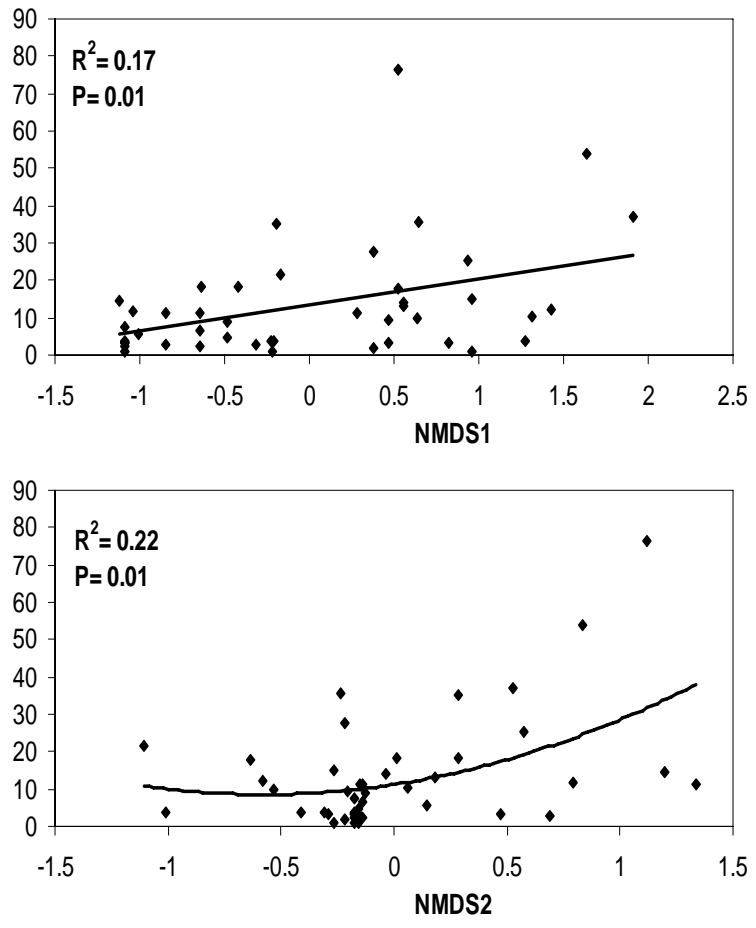

Figure 2.4 The relationship between community composition and productivity (above- and below-ground) of the natural dry acidic sandy grasslands at 


\subsection{Discussion}

Most of the controversies regarding the diversity-productivity relationship are raised from two points: (i) the effect of various diversity components (species richness, evenness, community composition and functional diversity) on ecosystem processes, and (ii) the inconsistency between results obtained from the experimental and the observational approach (Huston, 1997; Grime, 1997; Diaz \& Cabido, 2001; Loreau et al., 2002; Hector et al., 2007). In the present experiment, the relationship between diversity and productivity in the semi-natural grasslands varied according to the used diversity measure (i.e. species richness, evenness, or community composition). The positive relationship between evenness and productivity at within-site as well as across-sites scale in the semi-natural grasslands indicates that evenness may affect ecosystem functions more than species richness. It has been hypothesized that evenness might be more related to productivity and nutrient cycling of the ecosystems than number of species (Wilsey \& Potvin, 2000). Compared to evenness, species richness is greatly influenced by sub-ordinate species that have low abundance, while those species would have negligible effects on productivity or other ecosystem functions (Tilman et al., 1997; Spehn et al., 2002; Laird et al., 2003; Kahmen et al., 2005). Previous studies also indicated that species richness showed only weak relationships with productivity (Tilman et al., 1997; Kahmen et al., 2005).

Our results indicate that species composition is an important factor that might be related to the productivity of the natural and semi-natural grasslands (Tables 2.3 and 2.4; Figure 2.2 and 2.4). In contrast to species richness, community composition showed significant relationships with productivity for most of the surveyed sites, at least for one NMDS axis. Community composition is a complex measure of species diversity because it combines several aspects of diversity such as species richness, evenness, species identity as well as the interactions among the species. Thus, the relationship between diversity and productivity of natural and seminatural communities might be more related to species composition than to species number (Hooper \& Vitousek 1997; Grime, 1997; Laird et al., 2003; Kahmen et al., 2005; Grace et al., 2007).

Contrary to the semi-natural sites, none of the natural dry acidic sites showed a significant relationship between diversity and above-ground productivity at within-site scale. Previous studies (eg. Laird et al., 2003) have shown a significant relationship between diversity and productivity in sites characterized as early successional. Our results could be explained with 
regard to the fact that the variations in diversity and productivity levels within each site of the dry acidic grassland were too low to produce statistically significant relationship (Table 2.1).

Overall, our analysis at within-site scale indicates that there is no general relationship between plant diversity and productivity that is consistent for all sites and that the type of the diversityproductivity relationship could be influenced by the existing environmental conditions. Therefore, our results are not in agreement with the results obtained from experimental grasslands where an asymptotic increase in productivity along with increasing species richness was found (Hector et al., 1999).

Our analysis at across-sites level allows comparing our results with the observational approach as both of them investigate the diversity-productivity relationship across environmental gradients. The results obtained from the semi-natural grasslands (Figure 2.1) showed a general positive diversity-productivity relationship when the diversity measure was evenness. However, species richness showed no significant relationship with productivity nor did it behave according to the hypothesized hump-backed model (Grime, 1973). The explanation for this might be that obtaining the hump-shaped relationship requires the extreme environmental conditions to be included into the surveyed plots (disturbance or other stress factors at one end and conditions that favor high productivity at the other end). A lack of these extreme conditions which cause low and high productivity levels would produce a diversity productivity relationship that is located at the center of the hump-shaped curve (Figure 2.1). Another explanation could also be that the complementarity between species does not increase with increasing number of species (redundancy) in semi-natural grasslands (Laird et al., 2003). This is confirmed by the positive species richness-productivity relationship in the natural dry acidic grasslands (Figure 2.3), which is characterized by a lower number of species compared to semi-natural grasslands.

Interestingly, our results of the natural dry acidic grasslands at across-site scale are in agreement with the results obtained from the experimental approach (e.g., Naeem et al., 1996; Hector et al., 1999). In those experiments, the positive relationship has been mainly attributed to niche complementarity and sampling effect, where it has been argued that the diversity effect could also be driven by the plots with low species richness (Kahmen et al., 2005). In our natural dry acidic grasslands, it seems that those factors might also play an important role in producing such positive relationships in early successional sites because of the low species 
number and of ecological processes which have not yet reached equilibrium (Wardle, 1999; Laird et al., 2003).

Our results indicate that the relationship between species richness and ecosystem productivity is different for semi-natural and the nutrient poor dry acidic grasslands. Compared to seminatural grasslands, natural dry acidic grasslands are characterized by lower fertility and lower water availability during the growing season due to the low water holding capacity of the sandy soils. Diversity (species richness) effects might be stronger in low productive nutrient poor grasslands than in semi-natural grasslands, as plant species from semi-natural grasslands could be functionally more redundant compared to plant species from nutrient poor grasslands. This might explain why increasing species number was accompanied by higher productivity in the dry acidic, but not in semi-natural grasslands, at across-site scale. On the other hand, it may also be that there is no causal relationship between the higher biomass values and the higher species richness values in our natural dry acidic grasslands and that the observed positive relationship might just be due to the fact that the higher species numbers in the more productive plots results from a better species establishment in these plots after disturbance (Laird et al., 2003).

\subsection{Conclusions}

A reconciliation of the results obtained from the experimental and the observational approaches might enable us to understand the factors that regulate the relationship between biodiversity and ecosystem functioning as well as expand our current knowledge of conservation and ecosystem processes in natural ecosystems. We think that a single general diversity-productivity relationship does not properly characterize the investigated natural and semi-natural communities, thus biotic and/or abiotic factors might affect this relationship significantly. We suggest that future experiments should be continued in natural or seminatural ecosystems and that the investigated sites should be pre-classified according to their differences in ecological, compositional, or environmental characteristics. There is a need to include environmental factors in the future studies (rather than to control them) in order to investigate their effects on the biodiversity-productivity relationship. 


\section{The effect of dandelion (Taraxacum officinale Web.) as a constituent of seed mixtures on herbage production and weed infestation of perennial ryegrass-white clover swards}

\subsection{Abstract}

The effect of dandelion (Taraxacum officinale Web.) on the performance of a ryegrass-white clover mixture, in terms of total herbage yield, weed infestation, and $\mathrm{N}$ yield, was investigated in a replacement series experiment over three harvest years. The three species were grown in monocultures as well as in all possible combinations of binary and three-species mixtures under two nitrogen $(\mathrm{N})$ fertilization levels. Herbage yield and $\mathrm{N}$ yield of the three-species mixture were not significantly different from that of the ryegrass-white clover mixture over the three years. However, the dandelion proportion from the total herbage yield increased notably over years, especially in the fertilized swards. $\mathrm{N}$ application significantly increased the herbage yield of ryegrass and dandelion but not that of white clover. A competition analysis, performed by calculating relative yield and relative yield total indicated that ryegrass had a competitive advantage over white clover in fertilized and unfertilized swards, but over dandelion only when the sward was fertilized. On the other hand, dandelion had the competitive advantage over white clover under both $\mathrm{N}$ levels. $\mathrm{N}$ application reduced the nonsown species yield in all mixtures, except that of white clover-dandelion. Lower non-sown species yields were recorded in swards containing ryegrass.

\subsection{Introduction}

Perennial ryegrass (Lolium perenne L.) and white clover (Trifolium repens L.) are the dominant constituents of grassland for intensive dairy and beef husbandry in temperate climates throughout the world and they are frequently used in seed mixtures. When nitrogen fertilization is limited, white clover is the main source of nitrogen for herbage growth and animal nutrition (Elgersma \& Schlepers, 1997). As a feed for ruminants, white clover has high nutritional value and intake characteristics, resulting in improved levels of animal performance, including increased milk production and higher liveweight gain (Newton, 1993). Usually, white clover is grown with one or more grass companions; the most common being perennial ryegrass (Hill \& Michaelson Yeates, 1987). Broadening the number of sown species above ryegrass and white clover is a common practice in temperate grassland farming (Sanderson et al., 2004). However, sown species mainly belong to the grass family, apart from 
legume species, forbs are hardly considered in this respect (Sheldrick, 2000). Findings from recent ecological research on the relationship between grassland biodiversity and ecosystem services including sward productivity give reason to reconsider the inclusion of a variety of forage species into seed mixtures rather than sowing simple mixtures or monocultures (Hector \& Loreau, 2005). It has been suggested that ecosystems with a greater diversity of functional traits will operate more efficiently with higher productivity and resilience via more efficient retention of the soil nutrients and water as well as light resources (Tilman, 1997; Hooper \& Vitousek, 1997).

The species composition of grassland affects the exploitation of resources through complementarity and niche differentiation. Growing plant species with different functional attributes is believed to increase the spectrum at which resources are consumed by the plants (Vitousek \& Hooper, 1993). Seasonal complementarity among functional groups, dominance of different resources by different groups, and spatial complementarity within seasons are suggested means by which different species composition affects the efficiency of resource use (Vitousek \& Walker, 1989; Wedin \& Tilman, 1990; Chapin et al., 1995). In a recent experiment, it was found that the addition of only few species to a common two species seed mixture of grass and clover could improve sward productivity. It was concluded that growing three or four well adapted species rather than using more complex mixtures would give a production advantage (Tracy \& Sanderson, 2004a). Novel species such as the grassland forbs ribwort plantain (Plantago lanceolata L.) and chicoree (Cychorium intybus L.) have been suggested to support forage production and animal feeding in temperate climates and have been included into seed mixtures for grassland establishment (Li and Kemp, 2005; Labreveux et al., 2006).

One of the most widespread grassland species in Europe is dandelion (Taraxacum officinale Weber). Dandelion is considered as a weed infesting pastures, forage crops, and roadside verges (Stewart-Wade et al., 2002). The species colonizes numerous different habitats, grows in a diversity of soil types, resists drought and adapts to a wide range of light and shade intensities (Abu-Dieyeh \& Watson, 2007). Little attention has been paid to the forage potential of dandelion nor has it been considered for seed mixtures. However, due to its vigorous growth, deep rooting system, good adaptation to varying environmental conditions and reasonable feeding value it might support production and resilience of grass swards through traits complementary compared to common components of seed mixtures (Stewart- 
Wade et al., 2002). Currently, very little information is available on the effect of dandelion on the performance of ryegrass-white clover mixtures. A better knowledge of the effect of dandelion on the performance of mixed ryegrass-white clover swards would allow farmers to maximize sward performance and optimize sward management. Dandelion that grows in mixture with ryegrass and white clover may improve nutrient retention as well as yield stability of the mixture.

The main objective of the present study is to quantify the effect of dandelion on the agronomic performance of perennial ryegrass-white clover mixtures. The hypothesis was that adding dandelion to ryegrass-white clover mixtures would improve herbage yield, nitrogen retention, and decrease weed invasion. A field experiment was set up with monocultures and mixtures of the respective species in a replacement series where competition and complementary effects of species in the mixtures could be separated.

\subsection{Materials and Methods}

\section{Site description}

The experiment was established in Giessen ( $50^{\circ} 30^{\prime} \mathrm{N}, 8^{\circ} 41^{\prime} \mathrm{E}, 250$ a.s.1.), Central Germany, on soil classified as Haplic luvisol (FAO). Chemical characteristics of the soil (0-30 cm depth) were: $\mathrm{pH} 6.2$ (0.01 M CaCl2), $2.1 \%$ organic matter, $23 \mathrm{mg} \mathrm{P}_{2} \mathrm{O}_{5} \mathrm{~kg}^{-1}$ and $12 \mathrm{mg} \mathrm{K}_{2} \mathrm{O} \mathrm{kg}^{-1}$. The long-term management of the site was an arable crop rotation including leys. The preceding crop was winter barley. In the establishment year, the site was ploughed and harrowed, and then all plots were sown by seed broadcasting.

Weather data during the period of the experiment were obtained from the nearest weather station located $3 \mathrm{~km}$ from the site of the experiment. Temperature and precipitation data are presented in Table 3.1 .

Table 3.1 Average air temperature $\left({ }^{\circ} \mathrm{C}\right.$ at $\left.2.0 \mathrm{~m}\right)$ and precipitation $(\mathrm{mm})$ expressed as quarterly values for the study area.

\begin{tabular}{lccccccccc}
\hline & \multicolumn{3}{c}{ Temperature $\left({ }^{\circ} \mathrm{C}\right)$} & & \multicolumn{3}{c}{ Precipitation $(\mathrm{mm})$} \\
\cline { 2 - 4 } \cline { 7 - 9 } Period & $1^{\text {st }}$ year & $2^{\text {nd }}$ year & $3^{\text {rd }}$ year & Avg. & & $1^{\text {st }}$ year & $2^{\text {nd }}$ year & $3^{\text {rd }}$ year & Avg. \\
\hline Jan-Mar & 3.5 & -0.1 & 2.3 & 1.9 & & 196 & 82 & 115 & 131 \\
Apr-Jun & 12.7 & 12.1 & 10.2 & 11.7 & & 145 & 140 & 159 & 148 \\
Jul-Sep & 17.3 & 15.0 & 15.0 & 15.8 & & 234 & 198 & 70 & 167 \\
Annual & 9.6 & 7.9 & 8.1 & 8.5 & & 676 & 615 & 554 & 615 \\
\hline
\end{tabular}




\section{Treatments and experimental design}

Seven swards were established, three monocultures, ryegrass (G), white clover (C), and dandelion (D); three binary mixtures, ryegrass-white clover (GC), ryegrass-dandelion (GD) and white clover-dandelion (CD); and the three-species mixture of ryegrass, white clover and dandelion (GCD). A replacement series design was employed. Seeding rate was held constant for all swards (2000 germinable seeds per $\mathrm{m}^{2}$ ). Mixtures were established by reducing seed number per species by $50 \%$ (i.e. 1000 seeds per species) in the two-species mixtures or by $67 \%$ (i.e. 667 seeds per species) in the three-species mixture.

The ryegrass cultivar used was "Liprior" while for white clover, this was "Lirepa", with 1000 seed weight of $1.7 \mathrm{~g}$ and $0.6 \mathrm{~g}$, respectively. For dandelion, seeds were collected in the spring of the year that preceded the establishment year from a mesotrophic hay meadow in the proximity of the experimental site, with $0.7 \mathrm{~g}$ per 1000 seeds.

$\mathrm{N}$ fertilizer was applied at either 0 or $200 \mathrm{~kg} \mathrm{~N} \mathrm{ha}^{-1}$ year $^{-1}$ as calcium ammonium nitrate in equal doses to each of the defoliations. During the course of the experiment, no lime or fertilizers other than $\mathrm{N}$ were applied.

The experimental design was a split-plot with $\mathrm{N}$ fertilization treatments arranged in the main plots and swards in the subplots. Total area of the sub plot was $21 \mathrm{~m}^{2}(3 \mathrm{~m} \times 7 \mathrm{~m})$. There were four replications. In the establishing year, all swards were cut once, in autumn, yield was not measured.

\section{Measurements}

Above ground herbage yield was measured by harvesting the whole plot area $\left(21 \mathrm{~m}^{2}\right)$ with a Haldrup $^{\circledR}$ forage harvester, leaving stubble of $7 \mathrm{~cm}$. In the first and second year, swards were cut four times but in the third year swards were cut three times because the productivity was low. Total yield was recorded immediately, and a subsample of the cut material was taken for the assessment of the percentage DM. A sub-sample of about $0.5 \mathrm{~kg}$ was hand-separated into ryegrass, white clover, dandelion, and non-sown species and dried at $103^{\circ} \mathrm{C}$ for $24 \mathrm{~h}$ to determine the botanical composition. Another bulked sub-sample was taken for each individual sward, dried at $60^{\circ} \mathrm{C}$ then milled to pass $1-\mathrm{mm}$ sieve and analyzed for total $\mathrm{N}$ content by the Kjeldahl method. 
To assess the productive performance of mixtures compared to monocultures, relative yield total (RYT; de Wit, 1960) was calculated for the two- and three-species mixtures. A T-test $(\mathrm{P}=0.01, \mathrm{df}=3)$ was used separately for each sward in order to test whether RYT values are significantly different from unity (among replications, $R=4$ ). Relative yield total summarizes the performance of a mixture as a whole without giving information about the performance of each species component. Therefore, relative yields of species in the binary mixtures were plotted versus its companion species to analyze which species has the competitive advantage over the other species in binary mixtures (Williams \& McCarthy, 2001).

Relative yield for species $\mathrm{i}$ in a binary mixture with species $\mathrm{j}$ was calculated as follows (Fowler, 1982):

$$
R Y_{i j}=Y_{i j} /(1 / 2 Y i),
$$

where $Y_{i j}$ is the yield of species $i$ in the mixture and $Y_{i}$ is the yield of species $i$ in the monoculture. Likewise, relative yield for species $i$ in three species mixture with species $j$ and $\mathrm{k}$ was calculated as follows:

$$
R Y_{i j k}=Y_{i j k} /\left(1 / 3 Y_{i}\right)
$$

where $Y_{i j k}$ is the yield of species $i$ in the mixture and $Y_{i}$ is the yield of species $i$ in the monoculture. Relative yield total (RYT) was calculated as the weighted average of the relative yield of the mixture components:

$$
\begin{gathered}
\mathrm{RYT}_{\mathrm{ij}}=1 / 2\left(\mathrm{RY}_{\mathrm{ij}}+\mathrm{RY}_{\mathrm{ij}}\right) \text { and } \\
\mathrm{RYT}_{\mathrm{ijk}}=1 / 3\left(\mathrm{RY}_{\mathrm{ijk}}+\mathrm{RY}_{\mathrm{ijk}}+\mathrm{RY}_{\mathrm{kij}}\right)
\end{gathered}
$$

\section{Statistical analysis}

Analyses of variance were carried out on total annual herbage and nitrogen yield of the sown species, and of the non-sown species yield. Because of the split plot design of the experiment and the repeated measurements which have been taken over years on the same field plot, several random sources of variation arisen in such conditions that should be accommodated by a mixed model (Piepho et al., 2003). Therefore, an analysis of variance was performed with the procedure mixed of SAS 8.01 (SAS Institute, Cary, NC). 
Total herbage annual yield of the sown species, the non sown species, and $\mathrm{N}$ yield were analyzed using the data for the three years together. To accommodate the repeated factor (year), the following model was fitted (Piepho et al., 2004):

$C_{i j k m}=\mu+F_{i}+S_{j}+(F S)_{i j}+Y_{k}+(F Y)_{i k}+(S Y)_{j k}+(F S Y)_{i j k}+R_{m}+(R Y)_{k m}+(F Y R)_{i k m}+$ $e_{i j k m}$;

where $\mu$ is general mean; $F_{i}$ is nitrogen effect $(i=1$ or 2$) ; S_{j}$ is sward effect $(j=1 \ldots 7) ;(F S)_{i j}$ is the interaction between nitrogen and sward; $\mathrm{Y}_{\mathrm{k}}$ is year effect $(\mathrm{k}=1$ or 2); (FY), (SY), and (FSY) are the interactions between year and nitrogen, year and sward, and between year and nitrogen and sward, respectively; $\mathrm{R}_{\mathrm{m}}$ is block effect $(\mathrm{m}=1 \ldots 4)$; (FYR) is the interaction between nitrogen and year and block; and e is the residual term. All effects other than $(\mathrm{FYR})_{\mathrm{ikm}}$ and $\mathrm{e}_{\mathrm{ijk}}$ (both considered as random) were considered as fixed effects. The assumptions of models were checked by graphical and numerical methods, which were box plots and Kolmogorov-Smirnov test for the normality of residuals and scatter diagrams of residuals and predicted values for the constancy of random variance. Data were square-root transformed where necessary to better satisfy model assumptions.

Table 3.2 F values and level of significances of ANOVA for effects of sward composition (Sward), nitrogen fertilizer rates $(\mathrm{N})$, and year (Year) on herbage, non-sown species and $\mathrm{N}$ yield.

\begin{tabular}{lccccccc}
\hline \multicolumn{1}{c}{ Variables } & Sward & $\mathrm{N}$ & Year & $\begin{array}{c}\text { Sward } \times \\
\mathrm{N}\end{array}$ & $\begin{array}{c}\text { Sward } \times \\
\text { Y }\end{array}$ & N $\times$ Year & $\begin{array}{c}\text { Sward } \times \\
\mathrm{N} \times \text { Year }\end{array}$ \\
\hline Herbage yield & $140.0^{* * *} \S$ & $302.8^{* * *}$ & $914.8^{* * *}$ & $41.7^{* * *}$ & $87.7^{* * *}$ & $87.5^{* * *}$ & $15.7^{* * *}$ \\
Yield of non sown & $60.1^{* * *}$ & $12.1^{\mathrm{NS}}$ & $299.3^{* * *}$ & $25.9^{* * *}$ & $52.2^{* * *}$ & $7.2^{*}$ & $4.8^{* * *}$ \\
$\begin{array}{l}\text { species } \\
\text { Nitrogen yield }\end{array}$ & $119.7^{* * *}$ & $64.7^{* * *}$ & $753.6^{* * *}$ & $9.7^{* * *}$ & $55.3^{* * *}$ & $14.1^{* * *}$ & $6.5^{* * *}$ \\
\hline
\end{tabular}

${ }^{\S} \mathrm{NS}$, not significant, ${ }^{*} \mathrm{P}<0.05 ; * * \mathrm{P}<0.01 ; * * * \mathrm{P}<0.001$.

\subsection{Results}

\section{Total herbage yield}

The effects of sward, N, years and their interactions on the total herbage yield were all highly significant $(\mathrm{P}<0.001$, Table 3.2). For the three years, $\mathrm{N}$ application increased the yield of ryegrass and dandelion monocultures but not that of white clover, though ryegrass was more 
responsive to $\mathrm{N}$ fertilization than dandelion (Figure 3.1). Regarding the binary and the threespecies mixtures, the yield was enhanced significantly by $\mathrm{N}$ addition for all mixtures except that of white clover-dandelion, where no significant effect was observed. This enhancement only came from the increase in ryegrass yield in the mixture, where it was almost doubled when the sward was fertilized, rather than from white clover or from dandelion yield, which was either not affected or decreased in response to $\mathrm{N}$ addition.

In the subsequent years, lower overall yields were observed for all swards compared to the first year. Over time, the effect of $\mathrm{N}$ was also diminished, though the yield of ryegrass was slightly increased in response to $\mathrm{N}$ application. However, the yield of white clover was highly reduced when the sward was fertilized. On the other hand, dandelion yield in the mixture increased significantly as a result of sward fertilization.

Figure 3.1 also shows the contribution of each species to the total harvested herbage yield over the three experimental years. Ryegrass contribution to the herbage yield increased over years only in the ryegrass-white clover mixture, but not when accompanied by dandelion. In the three-species mixture, the ryegrass percentage decreased over time from around 37 and $65 \%$ in the first year to around 18 and $15 \%$ in the third year for the unfertilized and fertilized swards, respectively. Dandelion exhibited the opposite trend of ryegrass, as, over time, its percentages increased from around 5 and $4 \%$ in the first year to around 35 and $40 \%$ in the third year under unfertilized and fertilized swards, respectively. The white clover percentage showed the lowest variation over time.

\section{Yield of non-sown species}

The yield of the non-sown species was low in the second and the third year compared to the first one (Figure 3.2). The effects of swards, years as well as their interactions with $\mathrm{N}$ application were significant $(\mathrm{P}<0.05$, Table 3.2). In the first year, higher yields of non-sown species were recorded in monocultures of white clover and dandelion compared to ryegrass (Figure 3.2). $\mathrm{N}$ fertilization significantly increased the yield of the non-sown species in white clover and dandelion monocultures but not in those of ryegrass. Among the mixed swards, the highest herbage yield of the non-sown species was recorded for the white clover-dandelion mixture. On the other hand, $\mathrm{N}$ application reduced the non-sown species yield in all mixtures, except that of white clover-dandelion. In the subsequent years, the yield of the non-sown 
species decreased significantly compared to the first year for both monocultures and mixtures, except for the ryegrass-dandelion mixture.
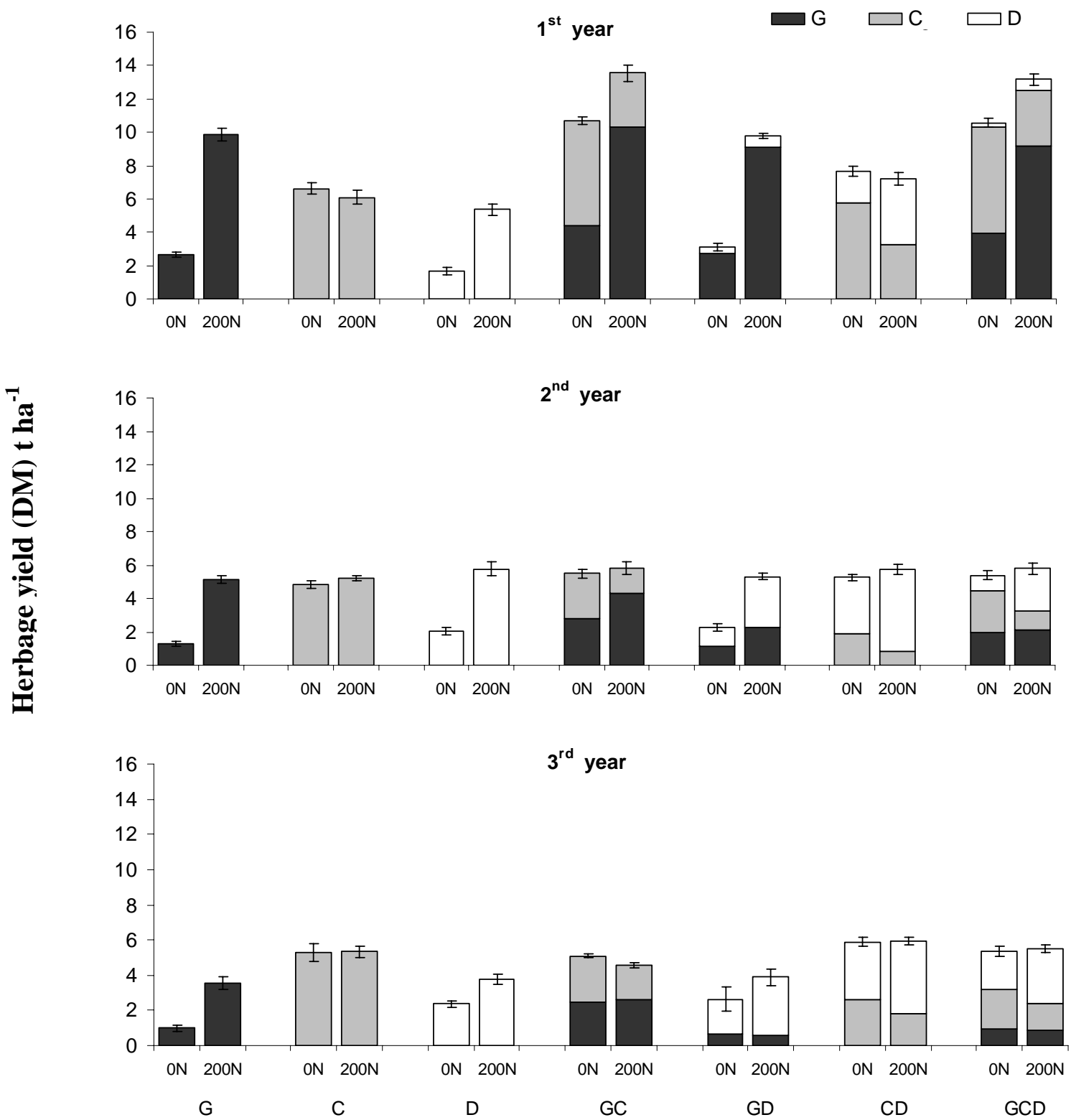

Figure 3.1 Annual herbage yield ( $\left.\mathrm{t} \mathrm{ha}^{-1}\right)$ of monocultures and mixtures of ryegrass $(\mathrm{G})$, white clover (C), and dandelion (D) under two nitrogen fertilizer levels ( 0 and $200 \mathrm{~kg} \mathrm{~N} \mathrm{ha}^{-1}$ ) for three subsequent years (vertical bars indicate $+/-$ s.e.m.). 


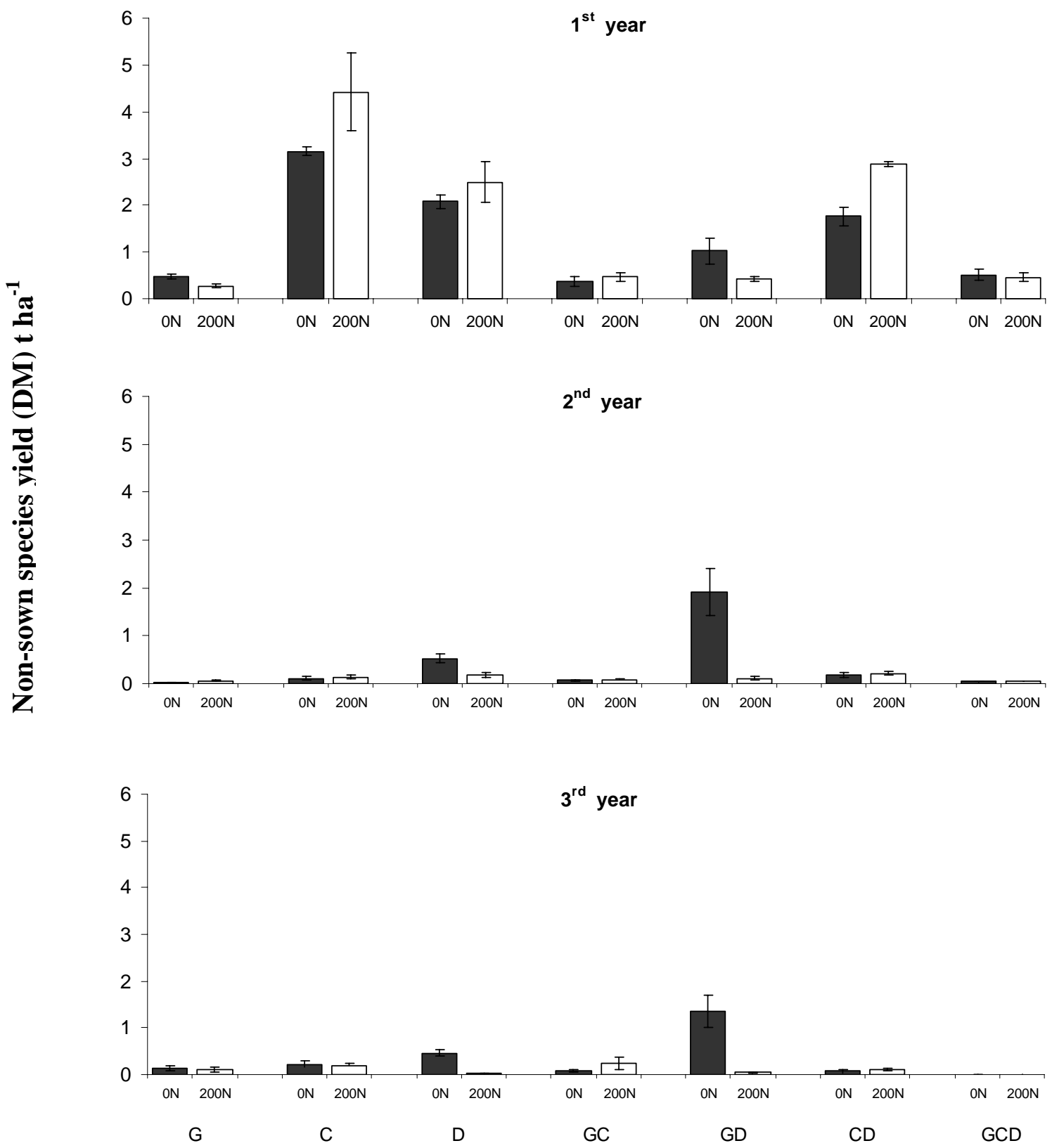

Figure 3.2 Yield of the non-sown species $\left(\mathrm{t} \mathrm{ha}^{-1}\right)$ of monocultures and mixtures of ryegrass $(\mathrm{G})$, white clover (C), and dandelion (D) under two nitrogen fertilizer levels $(0$ and $200 \mathrm{~kg} \mathrm{~N} \mathrm{ha}^{-1}$ ) for three subsequent years (vertical bars indicate $+/$ - s.e.m.).

\section{$\mathbf{N}$ yield}

Table 3.2 shows that the effects of sward, $\mathrm{N}$, and years and their interactions on $\mathrm{N}$ yield were all highly significant $(\mathrm{P}<0.001)$. $\mathrm{N}$ yield differences between the monocultures were consistent for the three years (Figure 3.3) with the highest $\mathrm{N}$ yield being obtained from white clover, followed by dandelion and ryegrass swards, respectively. $\mathrm{N}$ application significantly 
increased $\mathrm{N}$ yield in dandelion and ryegrass monocultures, but had no effect on $\mathrm{N}$ yield of white clover swards.

Regarding the mixtures, ryegrass-white clover and ryegrass-white clover-dandelion produced the highest $\mathrm{N}$ yield compared to the rest of the mixtures. However, the lowest $\mathrm{N}$ yield was observed for the ryegrass-dandelion mixture. In the first year, $\mathrm{N}$ application had no significant effect on the $\mathrm{N}$ yield of the mixtures except of ryegrass-dandelion mixture, where $\mathrm{N}$ fertilization showed a strong effect. In the subsequent years (Figure 3.3), generally lower $\mathrm{N}$ yields were observed for all mixtures and $\mathrm{N}$ application had only slightly positive effects.
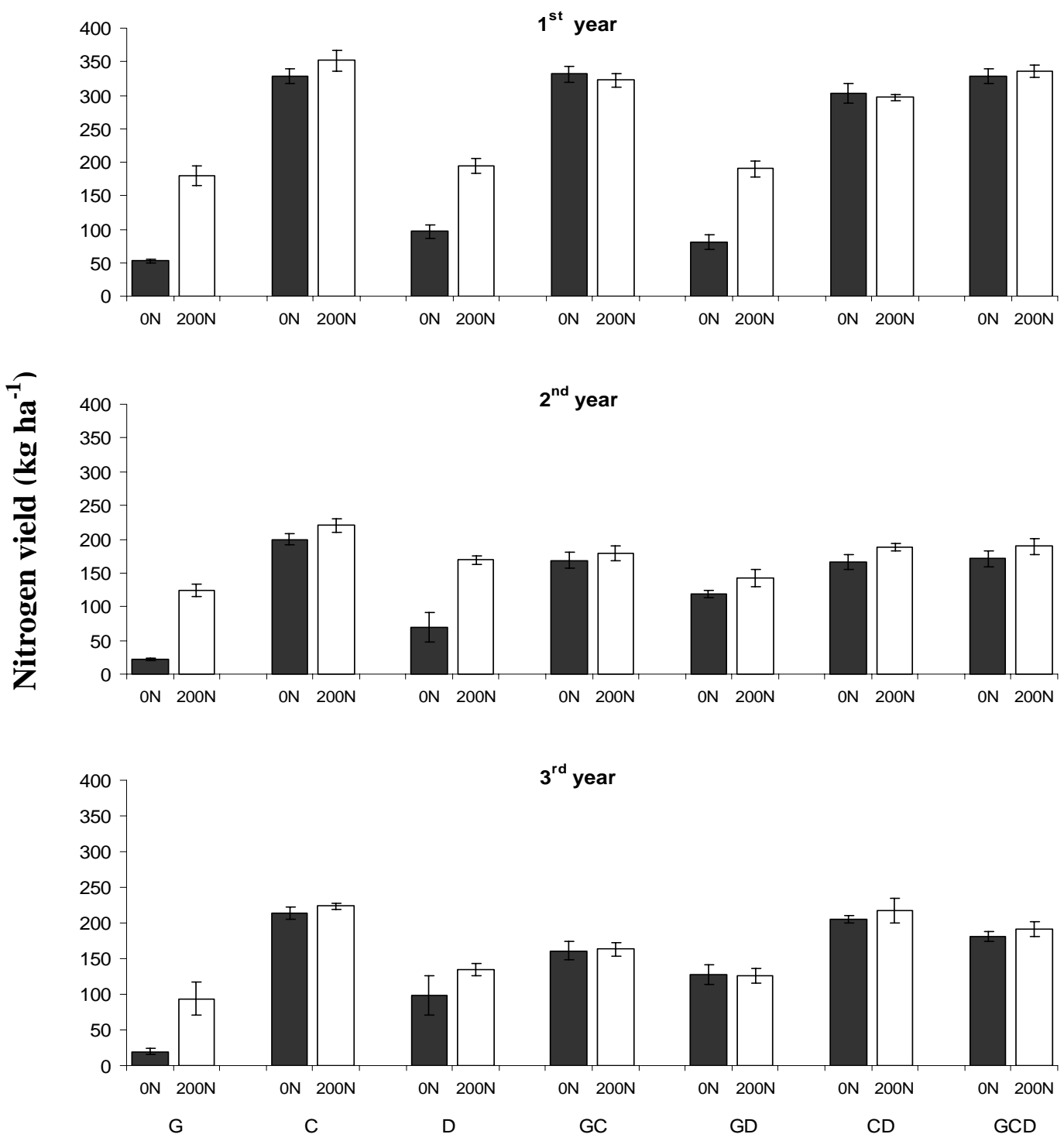

Figure 3.3 Nitrogen yield of monocultures and mixtures of ryegrass $(\mathrm{G})$, white clover (C), and dandelion (D) under two nitrogen fertilizer levels (0 and $200 \mathrm{~kg} \mathrm{~N}$ $\mathrm{ha}^{-1}$ ) for three subsequent years (vertical bars indicate $+/$ - s.e.m.). 


\section{Relative yield and relative yield total}

Relative yield total (RYT) values for the two and three species mixtures are shown in Table 3.3. Data being significantly different from unity are written in bold characters. They indicate that interspecific interactions are different from intraspecific ones (De Wit, 1960). Significant overyielding was only seen in mixtures containing white clover without $\mathrm{N}$ application. Lower RYT values were observed for swards that had received $\mathrm{N}$ application compared to those left unfertilized. Cases where RYT is significantly less than unity were not found in this experiment.

Plotting RY of a species against RY of its companion for the two species mixtures reveals important information about the performance of each species in the mixture compared to their performance in monoculture (Figure 3.4, detailed description in the footnote of the figure). The results show that no mixtures are located in $\mathrm{R} 1$ indicating that there is no case where both species are suppressed in mixtures compared to monocultures. In addition, all non-fertilized swards are located in R3 region, indicating that both species show overyielding in mixture compared to monoculture. Mixtures where one species is doing better in mixture than in monoculture while the other is suppressed in mixture compared to monoculture (R2 and R4) are ryegrass-white clover and white clover-dandelion mixtures, in both mixtures, white clover has been outcompeted by ryegrass and dandelion. Complete compensation between ryegrass and dandelion (i.e. $\mathrm{RYT}=1$ ) is observed when the sward is fertilized.

Table 3.3 Relative yield total (RYT) of ryegrass, clover, and dandelion in two- and threespecies mixtures.

\begin{tabular}{lcccc}
\hline Sward & $\begin{array}{c}\text { N-fertil. } \\
\mathrm{kg} \mathrm{ha}^{-1} \mathrm{a}^{-1}\end{array}$ & year 1 & $\begin{array}{c}\text { RYT } \\
\text { year 2 }\end{array}$ & year 3 \\
\hline GC & 0 & $\mathbf{2 . 6 0}$ & $\mathbf{2 . 7 2}$ & $\mathbf{3 . 0 5}$ \\
& 200 & $\mathbf{1 . 5 8}$ & 1.13 & 1.16 \\
GD & 0 & 1.24 & 1.43 & 1.76 \\
& 200 & 1.05 & 0.97 & 1.05 \\
CD & 0 & $\mathbf{1 . 9 8}$ & $\mathbf{2 . 0 8}$ & $\mathbf{1 . 9 5}$ \\
& 200 & 1.27 & 1.01 & $\mathbf{1 . 4 7}$ \\
GCD & 0 & $\mathbf{2 . 6 0}$ & $\mathbf{2 . 5 0}$ & $\mathbf{2 . 3 3}$ \\
& 200 & $\mathbf{1 . 6 0}$ & 1.07 & $\mathbf{1 . 3 6}$ \\
\hline
\end{tabular}

RYT values typed in bold cases are significantly different from unity (T-test, $\mathrm{P}=0.01, \mathrm{df}=3$ ). 


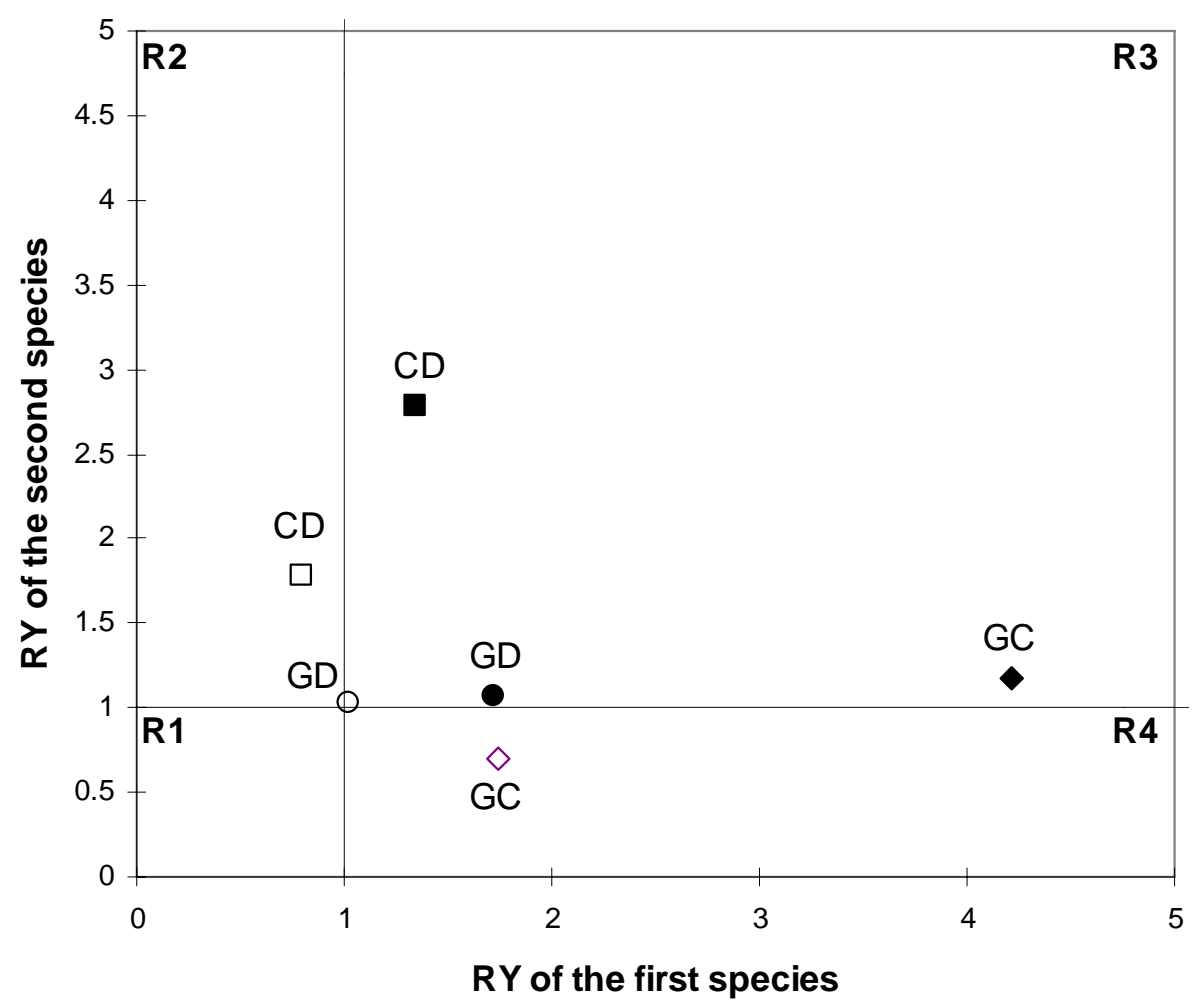

Figure 3.4 Plot of relative yield (RY) of one species against RY of its companion species in the binary mixtures. Dots in R1: indicate that both species are suppressed in mixture; R2 : indicate that the second species is doing better in mixtures than in monoculture, and is suppressing the first species; R3 : indicate that both species were doing better in the mixture than they did in monoculture showing facilitation of both species; R4: indicate the contrary of R2. Filled dots denote $(0 \mathrm{~N})$ while empty ones denote $(200 \mathrm{~N})$ treatments. Relative yields have been averaged over the three experimental years (after Williams and McCarthy, 2001).

\subsection{Discussion}

To overcome the limitations of the traditional ryegrass-white clover mixture such as sward persistence, diseases, weed infestation, there is a need to improve pasture diversity by integrating those species that naturally grow in pastures and are characterized by a high adaptability to the existing environmental conditions. Therefore, evaluating the potential of species with growth and nutritional characteristics that can be used to enhance sward performance is essential. From this point of view, dandelion could be a promising constituent of the traditional ryegrass-clover pastures.

In our experiment, all mixtures produced higher herbage yield compared to the monocultures of the components under both $\mathrm{N}$ levels. This is also confirmed by the RYT analysis (Table 3.2) which indicates that all mixtures have RYT values above unity as a sign for overyielding 
of mixtures compared to monocultures. However, the yield of the three-species mixture was not significantly different from that of the ryegrass-white clover mixture (Figure 3.1). This result can be attributed to the low contribution of dandelion to the herbage yield of the threespecies mixtures in the first year. In the subsequent years, the yield percentages of dandelion increased substantially in all mixtures, this contrasted sharply with the ryegrass herbage yield, which declined over time. This could be explained by the improving establishment of dandelion plants over time, especially building vigorous root systems which might have increased its competitive advantage. Generally, our results are in agreement with previous experiments which report that there is no yield advantage of complex mixtures over simple grass-legume mixtures (Annicchiarico et al., 1995; Tracy \& Sanderson, 2004b).

Other characteristics of pastures like yield stability, however, have been found to be more affected by increasing species diversity (Naeem \& Li, 1997; Tilman \& Downing, 1994). Higher numbers of sown species may help in reducing yield fluctuation within and among growing seasons through compensation effects, where stress tolerant species compensate for the reduction in herbage yield of the other species under stress conditions (MacGillivray et al., 1995; Tracy \& Sanderson, 2004a). Regarding our experiment, the total yields for all mixtures have declined in the second and third years. The reduction could be attributed to the observed lower temperature and precipitations in the second and third years compared to the first one (Table 3.1). However, it is worth noting that ryegrass and white clover were affected more negatively than dandelion. For the three-species mixture, the higher contribution of dandelion to the herbage yield in the second and third years partly compensated for the reduction in ryegrass and white clover yield and led to a better pasture stability across time as dandelion is better adapted to drought conditions (Abu-Dieyeh \& Watson, 2007).

Increasing plant diversity, species evenness, and managing species composition were found to reduce weed invasion in pasture communities (Tracy \& Sanderson, 2004b; Tracy et al., 2004; Kirwan et al., 2007). In the present experiment, the biomass of the unsown species was significantly lower in the three-species mixture compared to white clover and dandelion monocultures as well as to ryegrass-dandelion and white clover-dandelion mixtures. However, the yield of the non-sown species obviously decreased after the first year to reach negligible levels in the third year, which can be attributed to the closeness of the canopy as well as to the development of a vigorous root system that increased the competition of the sown species (Zemenchik et al., 2001). Among the monocultures, ryegrass showed the highest 
resistance to weed infestation in the first year compared to dandelion and white clover (Figure 3.2). The white clover monoculture was susceptible to weed infestation and showed the highest yield of the non-sown species in the first year. Apparently, this is due to a comparatively lower sward density and leaf area as well as to a lower competitiveness for soil $\mathrm{N}$ compared to other species. Nitrogen application increased the yield of the non-sown species in white clover and dandelion swards but not in ryegrass. This could be explained by the higher ability of ryegrass to absorb the major part of the available soil N (Høgh-Jensen \& Schjoerring, 1997), its extensive fibrous root system, and the better canopy cover compared to white clover and dandelion.

Nitrogen application significantly reduced the white clover yield in mixtures, but increased the yield of ryegrass and dandelion, particularly in the first year. This effect can be explained by the lower competitive ability of white clover when the sward is fertilized. Competition for light could be an important factor that governs the competitive ability of the three species in the mixed swards. When $\mathrm{N}$ is applied, light relations, especially within the upper layers of the canopy become more important in determining the growth of the species in mixed swards (Schwank et al., 1986; Faurie et al., 1996). Ryegrass and dandelion are more responsive to $\mathrm{N}$ fertilization, though adversely affected clover growth mainly through shading of white clover leaves and stolons (Haynes, 1980; Faurie et al., 1996). It has been reported that in ryegrass white clover mixtures, the height of white clover is shorter than that of perennial ryegrass during the whole growing season (Barthram \& Grant, 1994)

From an environmental as well as from an agronomic point of view, nitrogen fertilization should be aiming at balanced budgets, i.e. nitrogen losses into the environment should be avoided and nitrogen use efficiency of the grass sward should be high (Rochon et al., 2004). Our results, especially in the second and third years, indicate that there was no yield advantage of $\mathrm{N}$ application in mixtures that contained white clover. The low response of ryegrass- or dandelion-white clover mixtures to $\mathrm{N}$ application could be explained by the low competition between ryegrass and dandelion with white clover for the mineral $\mathrm{N}$ in the soil, as white clover relies on $\mathrm{N}_{2}$ fixation (Høgh-Jensen \& Schjoerring, 1997; Carlsson \& HussDanell, 2003).

Replacement series indices are commonly used in agricultural experiments to evaluate the yield advantage of mixtures compared to monocultures (De Wit, 1960). The relative yield 
total (RYT) is calculated by summing the relative yield of each species in the mixture. If RYT equals to 1.0 this means that the species are competing for the same resource(s), or they are equivalent to each other. Likewise, if RYT is greater than 1.0, this is an evidence for overyielding, which means that there is avoidance of competition. But when RYT is less than 1.0, mutual antagonism may be present between species (Williams \& McCarthy, 2001).

Generally, overyielding was only seen in mixtures of white clover without $\mathrm{N}$ application. Usually, mixtures of legume and non legume crops produce greater yield compared to monocultures of each species under low nutrient conditions (Ofori \& Stern, 1987). Niche differentiation $(\mathrm{RYT}>1)$ was not significant in ryegrass-dandelion mixtures over the three years and under both $\mathrm{N}$ treatments. For the three-species mixture, significant overyielding was detected under both $\mathrm{N}$ levels over the course of the experiment. This shows that niche differentiation was more obvious in the three-species mixture compared to the other mixtures. Spatial distribution of canopy and roots, as well as temporal separation of nutrient uptake might lead to the observed overyielding (Jumpponen et al., 2002).

The competition analysis based on the binary mixtures and shown in Figure 3.4 indicates that dandelion and ryegrass always have the competitive advantage over white clover, especially when the swards are fertilized. These results agree with those of Sanderson and Elwinger (1999) who reported that white clover produced higher herbage yields when grown in monoculture than in mixture with grasses, indicating significant competitive advantages of grasses over white clover. However, in mixtures of ryegrass and dandelion the species showed a similar competitive strength where no fertilizer nitrogen was applied while ryegrass was superior when the swards were fertilized.

\subsection{Conclusion}

The present experiment has investigated the potential value of dandelion as a constituent of seed mixtures of the pasture. Although there was no obvious yield advantage of growing dandelion, the herbage yield of the three-species mixture was not significantly lower than that of the ryegrass-white clover mixture. Regarding the fact that dandelion is naturally growing in most managed pastures, for the first time, our results indicate that the existence of dandelion in ryegrass-white clover pastures does not affect total herbage yield or $\mathrm{N}$ yield, nor does it reduce the percentage of white clover. Furthermore, dandelion might reduce the infestation of 
pasture weeds, enhance yield stability and improve the persistence of white clover in the pasture.

In conclusion, dandelion might have the potential of contributing to herbage yield, nutritive value, and weed resistance of ryegrass-white clover pastures. However, a better understanding of the management, attributes, and potential would also give impetus for future experiments to consider other aspects such as pasture persistence, seasonal variation and tolerance to grazing. 


\section{Contribution of dandelion (Taraxacum officinale Weber) to the mineral herbage yield (Ca, Mg, K, P, and Na) of perennial ryegrass-white clover mixture}

\subsection{Abstract}

The present experiment aimed to investigate the contribution of dandelion (Taraxacum officinale Weber) to the herbage mineral yield (calcium, magnesium, potassium, phosphorus, and sodium) of the traditional ryegrass-white clover mixture when dandelion is considered as a constituent of seed mixture. The grown species represent three perennials (forb, grass, and nitrogen-fixer) which differ in characteristics that are relevant to nutrient cycling (such as rooting depth, root to shoot ratio, size, and competitive ability in rich and poor environments). Ryegrass, white clover, and dandelion were grown in monocultures as well as in all possible mixtures with and without nitrogen fertilization $\left(0\right.$ and $\left.200 \mathrm{~kg} \mathrm{ha}^{-1}\right)$ in a replacement series experiment. Under both $\mathrm{N}$ levels, dandelion contains the highest concentrations $\left(\mathrm{g} \mathrm{kg}^{-1} \mathrm{DM}\right)$ of $\mathrm{Mg}, \mathrm{K}$ and $\mathrm{P}$, followed by white clover and ryegrass, respectively. The highest $\mathrm{Na}$ concentration was associated with white clover, where the difference between ryegrass and dandelion was statistically not significant $(\mathrm{P}>0.05)$. White clover monoculture produced the highest herbage mineral yield $\left(\mathrm{kg} \mathrm{ha}^{-1}\right)$ for the most tested minerals, followed by dandelion and ryegrass, respectively. This indicates the importance of white clover in pastures as a source of minerals for the animals and the companion crops in addition to the fact that dandelion herbage quality is higher than that of ryegrass. In general, Ca yield was decreased in most mixtures by $\mathrm{N}$ application, while $\mathrm{Mg}, \mathrm{K}$, and $\mathrm{P}$ yields were significantly increased as a result of $\mathrm{N}$ application in mixtures that contain dandelion. Sodium yield was increased by $\mathrm{N}$ application in ryegrass-white clover mixture, while decreased in the three-species mixture. In the second year of the experiment, the three-species mixture produced significantly higher $\mathrm{Ca}$ and $\mathrm{Mg}$ yield compared to ryegrass-white clover mixture, which attributed to the fact that $\mathrm{Ca}$ and $\mathrm{Mg}$ contents of dandelion are higher than ryegrass.

\subsection{Introduction}

Grass-clover swards are the most common forage mixtures in temperate regions. The yields and the herbage quality of these mixtures are suitable for intensive grazed areas that are suited for meat or diary production. The effect of cultivars, management and nitrogen $(\mathrm{N})$ fertilization on productivity and $\mathrm{N}$ use of grass-clover swards has been well studied (Tallowin et al., 1996; Loiseau et al., 2001; Sölter t al., 2007; Hakala \& Jauhiainen, 2007). However, in 
spite of its immense effect on herbage yield and animal health, herbage quality of these mixtures in terms of nutrients other than $\mathrm{N}$ such as phosphorus $(\mathrm{P})$, potassium $(\mathrm{K})$, magnesium $(\mathrm{Mg})$, calcium $(\mathrm{Ca})$, and sodium $(\mathrm{Na})$ has received little attention (Hopkins et al., 1994; McKenzie \& Jacobs, 2002).

Potential deficiencies or excesses of minerals in pasture are especially important, particularly where fertilizers are used (Hopkins et al., 1994; McKenzie \& Jacobs, 2002). Efficient growth of pasture is also dependent on adequate concentrations of mineral elements in the herbage. Sustainable agricultural systems, especially those relaying on organic farming, are more dependant on efficient cycling and use of nutrients particularly $\mathrm{P}$ and $\mathrm{K}$ within the farm (Fortune et al., 2005; Kayser \& Isselstein, 2005). For organic farming, balanced budget for N can be achieved to make inherently sustainable system. However, organic farms rely more on supplementary resources to achieve a sustainable balanced budget for P and K. (Berry et al., 2003)

One of the main advantages of growing species mixtures is to produce higher herbage yield. Growing species that differ is characteristics related to nutrients dynamics might also increase soil nutrients uptake by the plants which will increase the amount of minerals that are recovered in herbage yield (Vitousek \& Walker, 1989; Vinton \& Burke, 1995). This would help to reduce immediate losses of nutrients to the environment and also would improve nutrients recycling (Tallowin \& Brookman, 1996).

Species composition of the pasture may influence nutrient cycling through complementarity of resource use and niche differentiation, especially when different species are able to acquire nutrients from different portions of the available pool, which might lead to lower leaching of $\mathrm{N}$ and other nutrients (Bazzaz 1987; Vandermeer, 1989). In a large field experiment, Tilman et al. (1996) found that soil nitrate concentration is decreased as diversity increased. Their results suggest that plant diversity may reduce nitrogen leaching losses via nutrient use complementarity.

Introducing an herb species to ryegrass-white clover mixture may add another functional variation to it that might lead to improvement in nutrient retention as forbs have higher contents of minerals compared to grasses (Fisher et al., 1996). Dandelion (Taraxacum officinale Weber) is a perennial herb native throughout the northern hemisphere with many 
varieties and microspecies. Because dandelion has deep rooting system and has high concentration of $\mathrm{K}$, integrating dandelion with the ryegrass- white clover mixture could improve the nutritive value of this mixture and increase its response to $\mathrm{N}$ application. Yet, no previous published data was found describing the effect of dandelion as a potential component in mixture on herbage mineral yield of pastures.

To test our hypothesis, white clover, ryegrass, and dandelion were grown in monocultures as well as in all possible mixtures with and without $\mathrm{N}$ fertilization. Our objective was to assess the potential effect of dandelion on mineral herbage yields of $\mathrm{Ca}, \mathrm{Mg}, \mathrm{K}, \mathrm{P}$, and $\mathrm{Na}$ of the ryegrass-clover swards.

\subsection{Materials and Methods}

\section{Site description}

The experiment was established in Giessen ( $8^{\circ} 41^{\prime} \mathrm{N}, 50^{\circ} 30^{\prime} \mathrm{E}, 250$ a.s.1.), Central Germany, on soil classified as Haplic luvisol (FAO). Chemical characteristics of the soil (0-30 cm depth) were: $\mathrm{pH} 6.2$ (0.01 M CaCl2), $2.1 \%$ organic matter, $23 \mathrm{mg} \mathrm{P}_{2} \mathrm{O}_{5} \mathrm{~kg}^{-1}$ and $12 \mathrm{mg} \mathrm{K}_{2} \mathrm{O} \mathrm{kg}^{-1}$. The long-term management of the site was an arable crop rotation including leys. The preceding crop was winter barley. In the establishment year, the site was ploughed and harrowed, and then all plots were sown by seed broadcasting. Weather data during the period of the experiment were obtained from the nearest weather station located $3 \mathrm{~km}$ from the site of the experiment (Table 3.1).

\section{Treatments and experimental design}

Seven swards were established, three monocultures, ryegrass (G), white clover (C), and dandelion (D); three binary mixtures, ryegrass-white clover (GC), ryegrass-dandelion (GD) and white clover-dandelion (CD); and the three-species mixture of ryegrass, white clover and dandelion (GCD). A replacement series design was employed. Seeding rate was held constant for all swards (2000 germinable seeds per $\mathrm{m}^{2}$ ). Mixtures were established by reducing seed number per species by $50 \%$ (i.e. 1000 seeds per species) in the two-species mixtures or by $67 \%$ (i.e. 667 seeds per species) in the three-species mixture. The ryegrass cultivar used was "Liprior" while for white clover, this was "Lirepa", with 1000 seed weight of $1.7 \mathrm{~g}$ and $0.6 \mathrm{~g}$, respectively. For dandelion, seeds were collected in the spring of the year that proceeded the establishment year from a mesotrophic hay meadow in the proximity of the experimental site, with $0.7 \mathrm{~g}$ per 1000 seeds. 
The treatments imposed were a combination of sward mixtures and $\mathrm{N}$ fertilizer $(0$ and $200 \mathrm{~kg}$ $\mathrm{N} \mathrm{ha}^{-1}$ year $^{-1}$ ). $\mathrm{N}$ fertilizer was applied as calcium ammonium nitrate in equal doses to each of the defoliation period. During the course of the experiment, no fertilizers other than $\mathrm{N}$ were applied. The experimental design was a split-plot with $\mathrm{N}$ fertilization treatments arranged in the main plots and swards in the subplots. Total area of the sub plot was $21 \mathrm{~m}^{2}(3 \mathrm{~m} \times 7 \mathrm{~m})$. There were four replications. In the establishing year, all swards were cut once, in autumn, no measurements have been taken.

\section{Measurements}

Above ground herbage yield was measured (reported elsewhere) by harvesting the whole plot area $\left(21 \mathrm{~m}^{2}\right)$ with a Haldrup ${ }^{\circledR}$ forage harvester, leaving a stubble of $7 \mathrm{~cm}$. Swards were cut four times in each of two successive years. Sub-sample of the cut material was taken for each sward type, oven dried at $60^{\circ} \mathrm{C}$ for $72 \mathrm{~h}$, milled to pass 1-mm sieve and stored before analysis. Samples were analyzed for P according to Gericke and Kurmies (1952). For K, Mg, $\mathrm{Ca}$, and $\mathrm{Na}$, the analyses were done according to Schinkel (1984).

\section{Statistical analysis}

Analyses of variance were carried out on $\mathrm{P}, \mathrm{K}, \mathrm{Na}, \mathrm{Ca}$, and $\mathrm{Mg}$ yield of the swards using the data form the two years. Because of the split plot design of the experiment and the repeated measurements which have been taken over years on the same field plot, several random sources of variation arisen in such conditions that should be accommodated by mixed model (Piepho et al., 2003). Therefore, analysis of variance was performed with the procedure mixed of SAS 8.01 (SAS Institute, Cary, NC). To accommodate the repeated factor (year), the following model was fitted (Piepho et al., 2004):

$C_{i j k m}=\mu+F_{i}+S_{j}+(F S)_{i j}+Y_{k}+(F Y)_{i k}+(S Y)_{j k}+(F S Y)_{i j k}+R_{m}+(R Y)_{k m}+(F Y R)_{i k m}+$ $e_{i j k m}$

where $\mu$ is general mean; $F_{i}$ is the nitrogen effect $(i=1$ or 2$) ; S_{j}$ is the sward effect $(j=1 \ldots 7)$; $(\mathrm{FS})_{\mathrm{ij}}$ is the interaction between nitrogen and sward; $\mathrm{Y}_{\mathrm{k}}$ is year effect $(\mathrm{k}=1$ or 2); (FY), (SY), and (FSY) are the interactions between year and nitrogen, year and sward, and between year and nitrogen and sward, respectively; $\mathrm{R}_{\mathrm{m}}$ is block effect $(\mathrm{m}=1 \ldots 4) ;(\mathrm{FYR})$ is the whole-plot random error; and $\mathrm{e}_{\mathrm{ijkm}}$ is the sub-plot residual random error. All effects other than $(\mathrm{FYR})_{\mathrm{ikm}}$ and $\mathrm{e}_{\mathrm{ijk}}$ (both considered as random) were considered as fixed effects. The assumptions of 
models were checked by graphical and numerical methods, which were box plots and Kolmogorov-Smirnov test for the normality of residuals and scatter diagrams of residuals and predicted values for the constancy of random variance.

Analyses of variance for $\mathrm{P}, \mathrm{K}, \mathrm{Na}, \mathrm{Ca}$, and $\mathrm{Mg}$ concentrations were carried out using average data over the two years. The following model was fitted (same symbols as above):

$C_{i j m}=\mu+F_{i}+S_{j}+(F S)_{i j}+R_{m}+(F R)_{i m}+e_{i j m} ;$

Table 4.1 F values and level of significances of the effects of sward composition (Sward), nitrogen fertilizer rates $(\mathrm{N})$, and year (Year) on sward characteristics.

\begin{tabular}{|c|c|c|c|c|c|}
\hline Variables & Sward & $\mathrm{N}$ & Year & $\begin{array}{c}\text { Sward } \times \\
\mathrm{N}\end{array}$ & $\begin{array}{l}\text { Sward } \times \\
\mathrm{N} \times \text { Year }\end{array}$ \\
\hline $\begin{array}{l}\text { Annual Calcium yield } \\
\left(\mathrm{kg} \mathrm{Ca} \mathrm{ha}^{-1}\right)\end{array}$ & $129.1 * * *$ & $21.8 * * *$ & $465.5 * * *$ & $15.3 * * *$ & $6.3 * * *$ \\
\hline $\begin{array}{l}\text { Annual Magnesium yield } \\
\left(\mathrm{kg} \mathrm{Mg} \mathrm{ha}^{-1}\right)\end{array}$ & $146.0 * * *$ & $148.7 * *$ & $239.7 * * *$ & $28.1 * * *$ & $4.3^{*}$ \\
\hline $\begin{array}{l}\text { Annual Potassium yield } \\
\left(\mathrm{kg} \mathrm{K} \mathrm{ha}^{-1}\right)\end{array}$ & $21.7 * * *$ & $144.8 * * *$ & $1676.5 * * *$ & $7.5 * * *$ & $5.5 * * *$ \\
\hline $\begin{array}{l}\text { Annual Phosphorus yield } \\
\left(\mathrm{kg} \mathrm{P} \mathrm{ha}^{-1}\right)\end{array}$ & $199.6 * * *$ & $431.9 * * *$ & $823.7 * *$ & $31.4 * * *$ & $3.6 \mathrm{NS}$ \\
\hline $\begin{array}{l}\text { Annual Sodium yield } \\
\left(\mathrm{kg} \mathrm{Na} \mathrm{ha}^{-1}\right)\end{array}$ & $29.1 * * *$ & $5.0^{*}$ & $88.8^{* * *}$ & $2.3 \mathrm{NS}$ & $1.0 \mathrm{NS}$ \\
\hline $\begin{array}{l}\text { Calcium Concentration } \\
\left(\mathrm{g} \mathrm{kg}^{-1} \mathrm{DM}\right)\end{array}$ & $58.6 * * *$ & $17.2 *$ & - & $8.3 *$ & - \\
\hline $\begin{array}{l}\text { Magnesium Concentration } \\
\left(\mathrm{g} \mathrm{kg}^{-1} \mathrm{DM}\right)\end{array}$ & $81.8 * * *$ & $1.3 \mathrm{NS}$ & - & $7.0 * * *$ & - \\
\hline $\begin{array}{l}\text { Potassium Concentration } \\
\left(\mathrm{g} \mathrm{kg}^{-1} \mathrm{DM}\right)\end{array}$ & $34.1 * * *$ & $0.8 \mathrm{NS}$ & - & $8.1 * * *$ & - \\
\hline $\begin{array}{l}\text { Phosphorus Concentration } \\
\left(\mathrm{g} \mathrm{kg}^{-1} \mathrm{DM}\right)\end{array}$ & $33.4 * * *$ & 9.1 NS & - & $12.6 * * *$ & - \\
\hline $\begin{array}{l}\text { Sodium Concentration } \\
\left(\mathrm{g} \mathrm{kg}^{-1} \mathrm{DM}\right)\end{array}$ & $13.5 * * *$ & $0.7 \mathrm{NS}$ & - & $1.1 \mathrm{NS}$ & - \\
\hline
\end{tabular}




\subsection{Results}

Statistical analysis indicated that there is a significant effect of $\mathrm{N}$ application and sward type on mineral herbage yield (Table 4.1). In addition, interactions between the three studied factors (sward types, $\mathrm{N}$ application and year) are also statistically significant for all minerals except $\mathrm{Na}$ and $\mathrm{P}$ yields. The concentrations of minerals in herbage were significantly affected by sward type and the interaction between sward type and $\mathrm{N}$ levels; however, $\mathrm{N}$ application showed no significant effect on all mineral concentrations except $\mathrm{Ca}$.

Table (4.2) shows the concentrations $\left(\mathrm{g} \mathrm{kg}^{-1} \mathrm{DM}\right)$ of the tested minerals for each sward. Under both $\mathrm{N}$ levels, dandelion contains the highest concentrations of $\mathrm{Mg}, \mathrm{K}$ and $\mathrm{P}$, followed by white clover and ryegrass, respectively. Without $\mathrm{N}$ fertilization, dandelion contains significantly higher Ca concentration than white clover and ryegrass, but when the sward is fertilized, Ca concentration in dandelion herbage is reduced significantly to be lower than white clover. The highest $\mathrm{Na}$ concentration was associated with white clover, where the difference between ryegrass and dandelion was statistically not significant $(\mathrm{P}>0.05)$.

Annual herbage mineral yields $\left(\mathrm{kg} \mathrm{ha}^{-1}\right)$ of $\mathrm{Ca}, \mathrm{Mg}, \mathrm{K}, \mathrm{P}$ and $\mathrm{Na}$ for the mixtures are presented in figures (4.1-4.5). Calcium yield was generally decreased in the mixtures in response to $\mathrm{N}$ application, except for ryegrass-dandelion (Figure 4.1). However, in the second year, the effect of $\mathrm{N}$ application was statistically significant only for ryegrass-white clover sward, but not for the other mixtures. Dandelion contribution to the Ca yield was obvious only in the second year, where the three-species mixture produced significantly higher Ca yield than the ryegrass-white clover mixture.

On the contrary to $\mathrm{Ca}$ yield, $\mathrm{N}$ application positively affected $\mathrm{Mg}$ yield of most mixtures (Figure 4.2). However, this effect was only apparent in mixtures that contained dandelion, as $\mathrm{Mg}$ yield of the ryegrass-white clover mixture was not significantly affected by $\mathrm{N}$ application in both years. Interestingly, in the second year, the three-species mixture produced significantly $(\mathrm{P}<0.05)$ higher $\mathrm{Mg}$ yield than the ryegrass-white clover mixture under both $\mathrm{N}$ levels.

Herbage $\mathrm{K}$ and $\mathrm{P}$ yields were affected positively by $\mathrm{N}$ application (Figure 4.3 and 4.4 ), though the effect was only statistically significant in the first year. Compared to the binary mixture of 
ryegrass and white clover, there was no effect of dandelion on the $\mathrm{K}$ and $\mathrm{P}$ yield of the threespecies mixture under both $\mathrm{N}$ levels for the two successive years.

In the first year, $\mathrm{Na}$ yield was significantly decreased by $\mathrm{N}$ application in white cloverdandelion and in the three-species mixture, while increased as a result of $\mathrm{N}$ application in ryegrass-white clover and ryegrass-dandelion mixtures. However, the effect of $\mathrm{N}$ application was statistically significant $(\mathrm{P}<0.05)$ only in the first year for the ryegrass-dandelion and the three-species mixture.

Table 4.2 Concentrations of $\mathrm{Ca}, \mathrm{Mg}, \mathrm{K}, \mathrm{P}$ and $\mathrm{Na}\left(\mathrm{g} \mathrm{kg}^{-1} \mathrm{DM}\right)$ in herbage of pure stand and mixtures of ryegrass $(\mathrm{G})$, white clover (C), and dandelion (D) growing under two $\mathrm{N}$ levels $\left(0\right.$ and $\left.200 \mathrm{~kg} \mathrm{ha}^{-1}\right)$, data are average of two years.

\begin{tabular}{|c|c|c|c|c|c|c|}
\hline $\begin{array}{c}\text { Nitrogen } \\
\text { fertilization }\end{array}$ & Swards & $\mathrm{Ca}$ & $\mathrm{Mg}$ & $\mathrm{K}$ & $\mathrm{P}$ & $\mathrm{Na}$ \\
\hline \multirow[t]{7}{*}{$0 \mathrm{~N}$} & G & 7.0 & 1.8 & 23.3 & 3.9 & 0.5 \\
\hline & $\mathrm{C}$ & 20.7 & 3.5 & 31.9 & 5.6 & 2.5 \\
\hline & $\mathrm{D}$ & 26.0 & 6.0 & 55.3 & 7.8 & 1.1 \\
\hline & $\mathrm{GC}$ & 13.8 & 2.6 & 24.1 & 4.1 & 1.8 \\
\hline & GD & 17.3 & 3.9 & 38.0 & 5.8 & 1.1 \\
\hline & $\mathrm{CD}$ & 17.9 & 3.9 & 31.7 & 5.0 & 1.6 \\
\hline & GCD & 14.9 & 2.9 & 23.9 & 4.2 & 2.0 \\
\hline \multirow[t]{7}{*}{$200 \mathrm{~N}$} & $\mathrm{G}$ & 6.5 & 1.8 & 25.7 & 3.5 & 0.9 \\
\hline & $\mathrm{C}$ & 21.5 & 3.8 & 38.5 & 6.2 & 2.5 \\
\hline & D & 16.7 & 5.0 & 40.6 & 5.1 & 0.8 \\
\hline & $\mathrm{GC}$ & 9.5 & 2.2 & 25.3 & 4.0 & 1.9 \\
\hline & GD & 9.0 & 2.6 & 28.1 & 3.8 & 0.9 \\
\hline & $\mathrm{CD}$ & 17.8 & 4.6 & 34.8 & 5.3 & 1.6 \\
\hline & GCD & 11.5 & 2.8 & 28.7 & 4.1 & 1.4 \\
\hline $\mathrm{LSD}^{1}$ & & 2.8 & 0.6 & 5.7 & 0.7 & 0.7 \\
\hline $\mathrm{LSD}^{2}$ & & 3.2 & 0.7 & 5.7 & 0.8 & 0.7 \\
\hline
\end{tabular}

${ }^{1}$ LSD value within the same $\mathrm{N}$ level; ${ }^{2} \mathrm{LSD}$ value between different $\mathrm{N}$ levels. 
Table 4.3 Concentrations of $\mathrm{Ca}, \mathrm{Mg}, \mathrm{K}, \mathrm{P}$ and $\mathrm{Na}$ in herbage required by high-producing dairy cows (600 kg cow; 301 milk day $^{-1}$ ) (after McKenzie \& Jacobs, 2002).

\begin{tabular}{lc}
\hline Minerals & $\begin{array}{c}\text { Dairy cow requirements } \\
\left(\mathrm{g} \mathrm{kg}^{-1} \mathrm{DM}\right)\end{array}$ \\
\hline $\mathrm{Ca}$ & $3.4-4.0$ \\
$\mathrm{Mg}$ & $1.7-3.5$ \\
$\mathrm{~K}$ & 0.8 \\
$\mathrm{P}$ & $3.0-4.0$ \\
$\mathrm{Na}$ & 1.2 \\
\hline
\end{tabular}

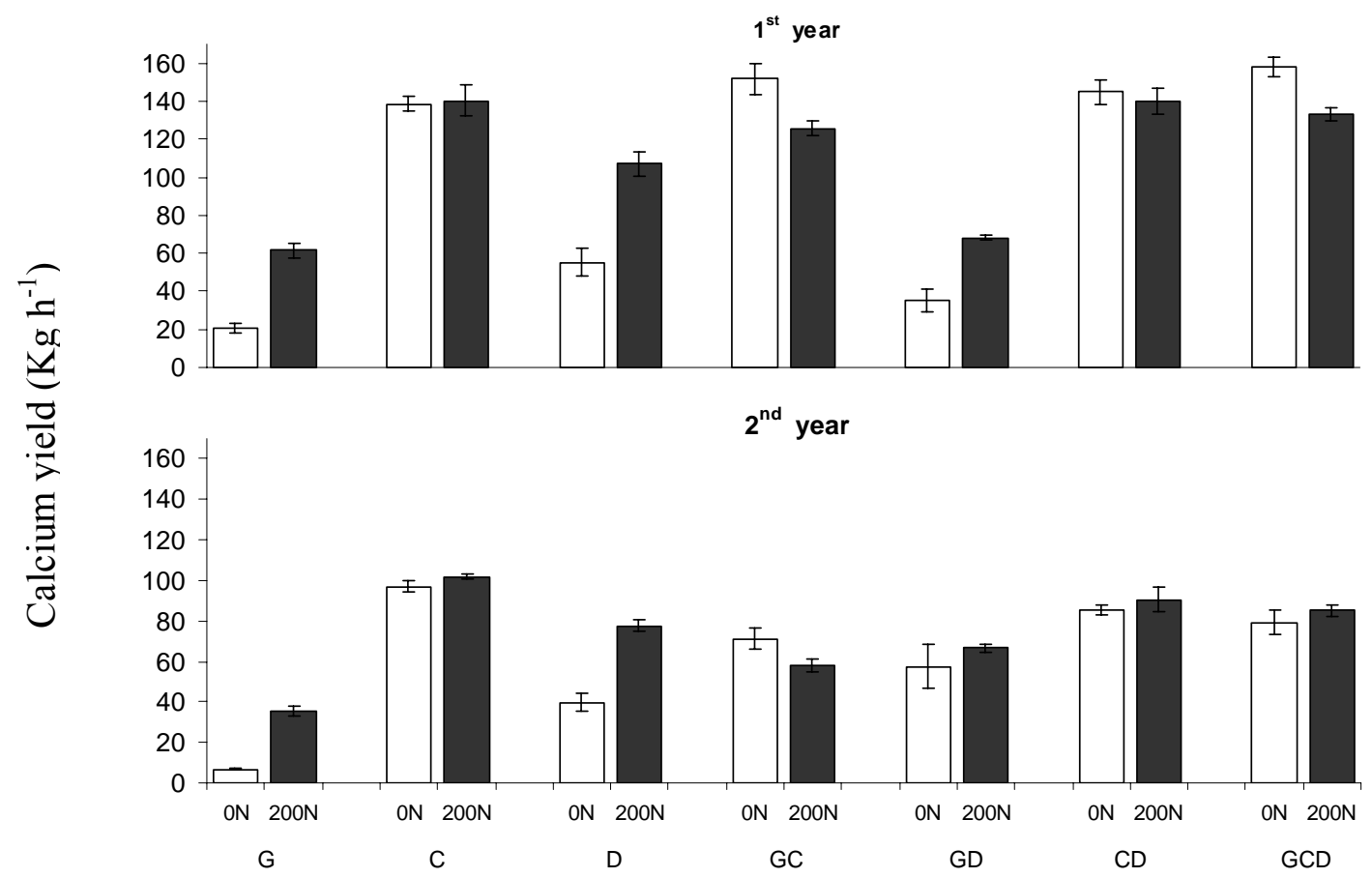

Figure 4.1 Mineral yield of $\mathrm{Ca}\left(\mathrm{kg} \mathrm{ha}^{-1}\right)$ in herbage of pure stand and mixtures of ryegrass $(\mathrm{G})$, white clover $(\mathrm{C})$, and dandelion (D) growing under two $\mathrm{N}$ rates $\left(0\right.$ and $\left.200 \mathrm{~kg} \mathrm{ha}^{-1}\right)$ for two subsequent years (vertical bars indicate $+/$ s.e.m.). 


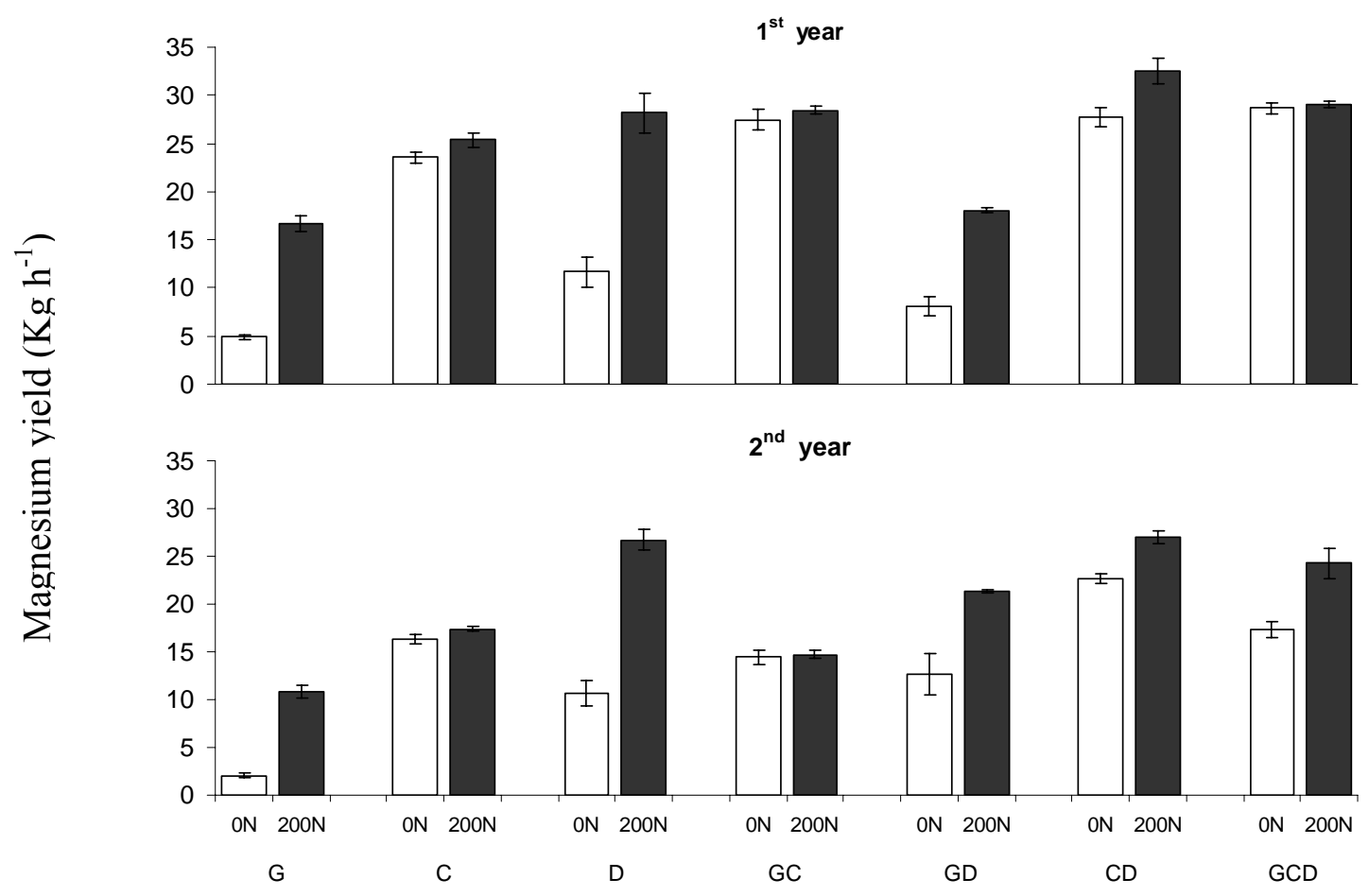

Figure 4.2 Mineral yield of $\mathrm{Mg}\left(\mathrm{kg} \mathrm{ha}^{-1}\right)$ in herbage of pure stand and mixtures of ryegrass $(\mathrm{G})$, white clover $(\mathrm{C})$, and dandelion $(\mathrm{D})$ growing under two $\mathrm{N}$ rates $\left(0\right.$ and $200 \mathrm{~kg} \mathrm{ha}^{-1}$ ) for two subsequent years (vertical bars indicate $+/-$ s.e.m.).

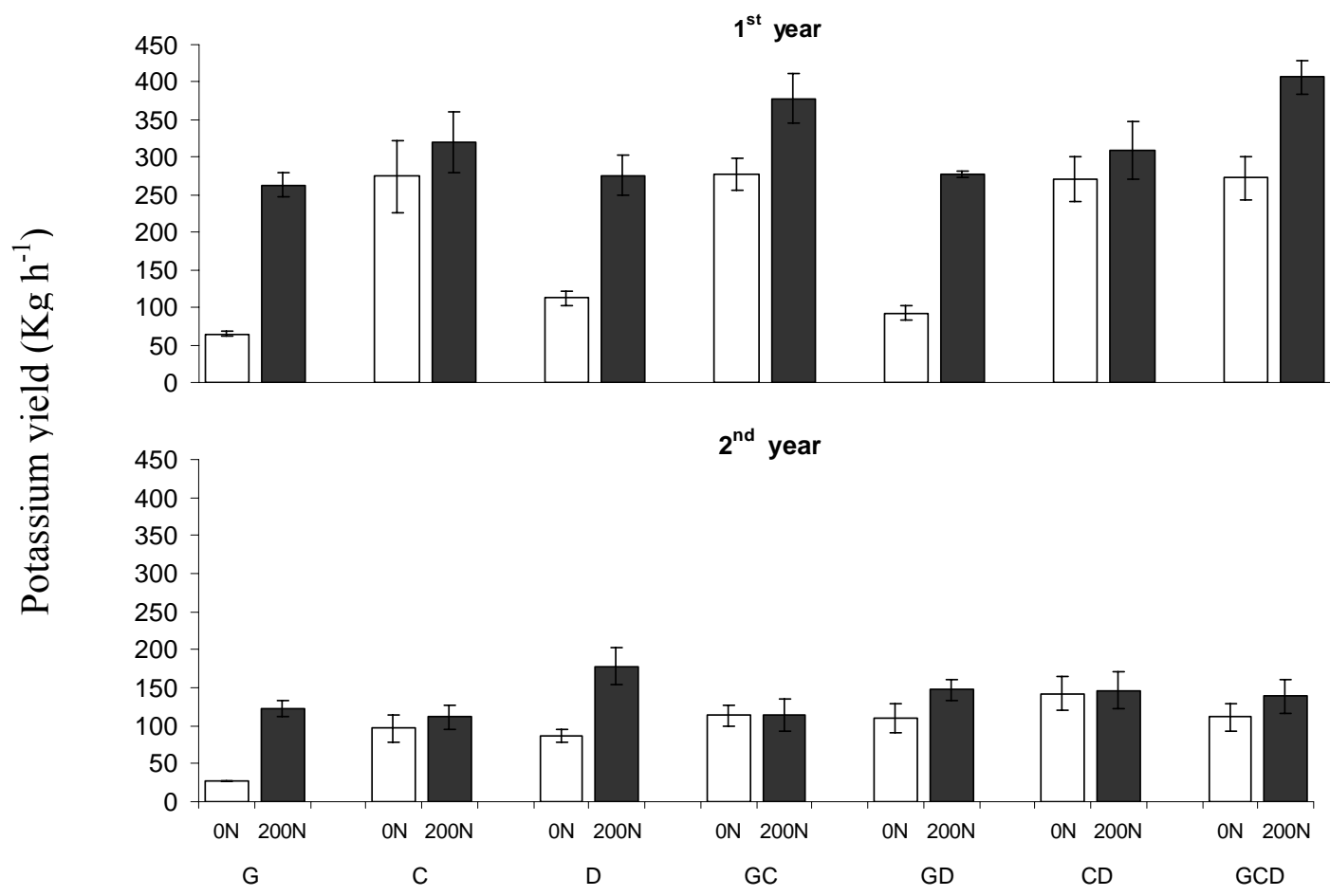

Figure 4.3 Mineral yield of $\mathrm{K}\left(\mathrm{kg} \mathrm{ha}^{-1}\right)$ in herbage of pure stand and mixtures of ryegrass $(\mathrm{G})$, white clover $(\mathrm{C})$, and dandelion (D) growing under two $\mathrm{N}$ rates $(0$ and $200 \mathrm{~kg} \mathrm{ha}^{-1}$ ) for two subsequent years (vertical bars indicate $+/$ - s.e.m.). 


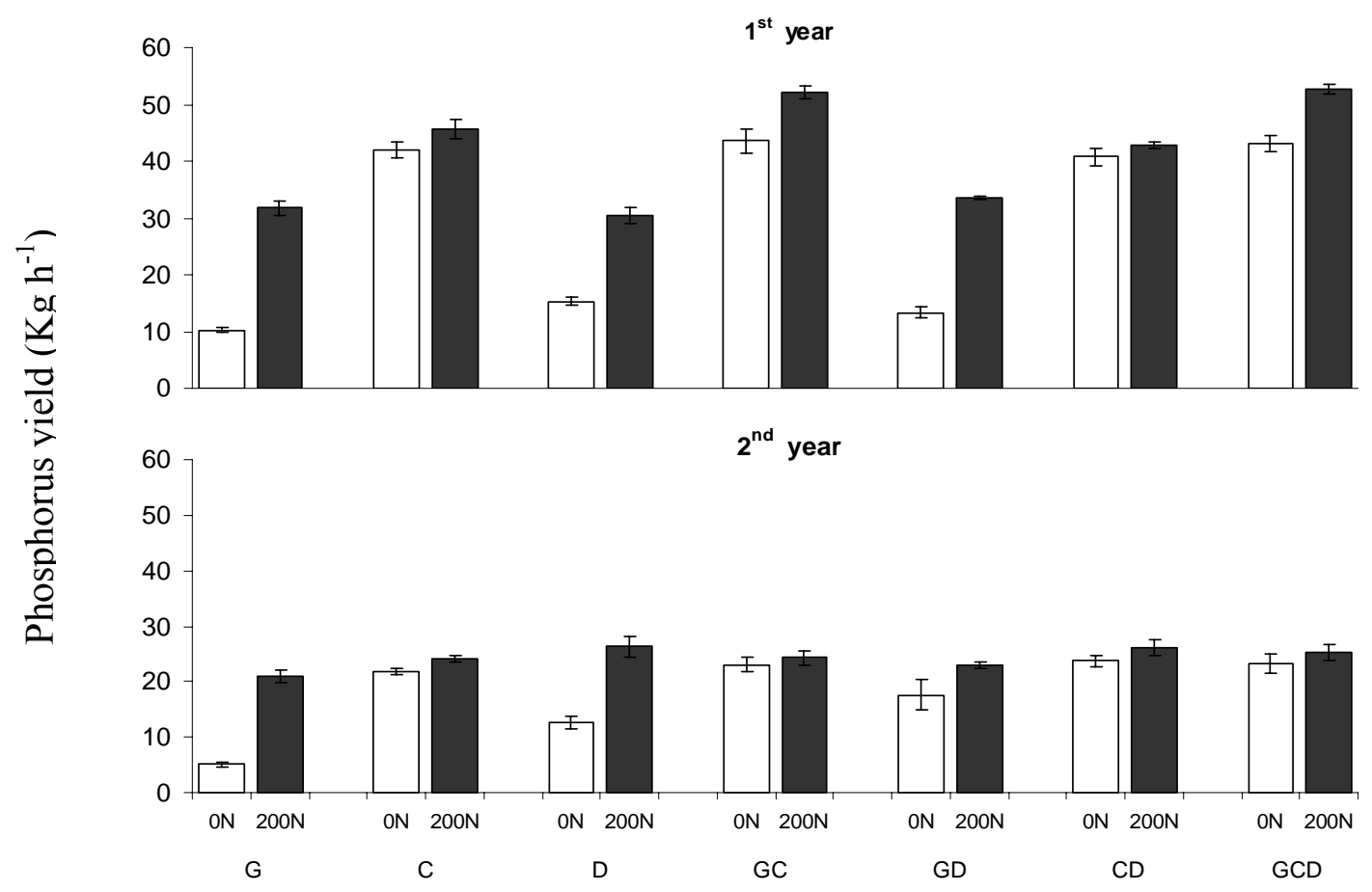

Figure 4.4 Mineral yield of $\mathrm{P}\left(\mathrm{kg} \mathrm{ha}^{-1}\right)$ in herbage of pure stand and mixtures of ryegrass $(\mathrm{G})$, white clover(C), and dandelion (D) growing under two $\mathrm{N}$ rates (0 and 200 $\mathrm{kg} \mathrm{ha}^{-1}$ ) for two subsequent years (vertical bars indicate $+/-$ s.e.m.).

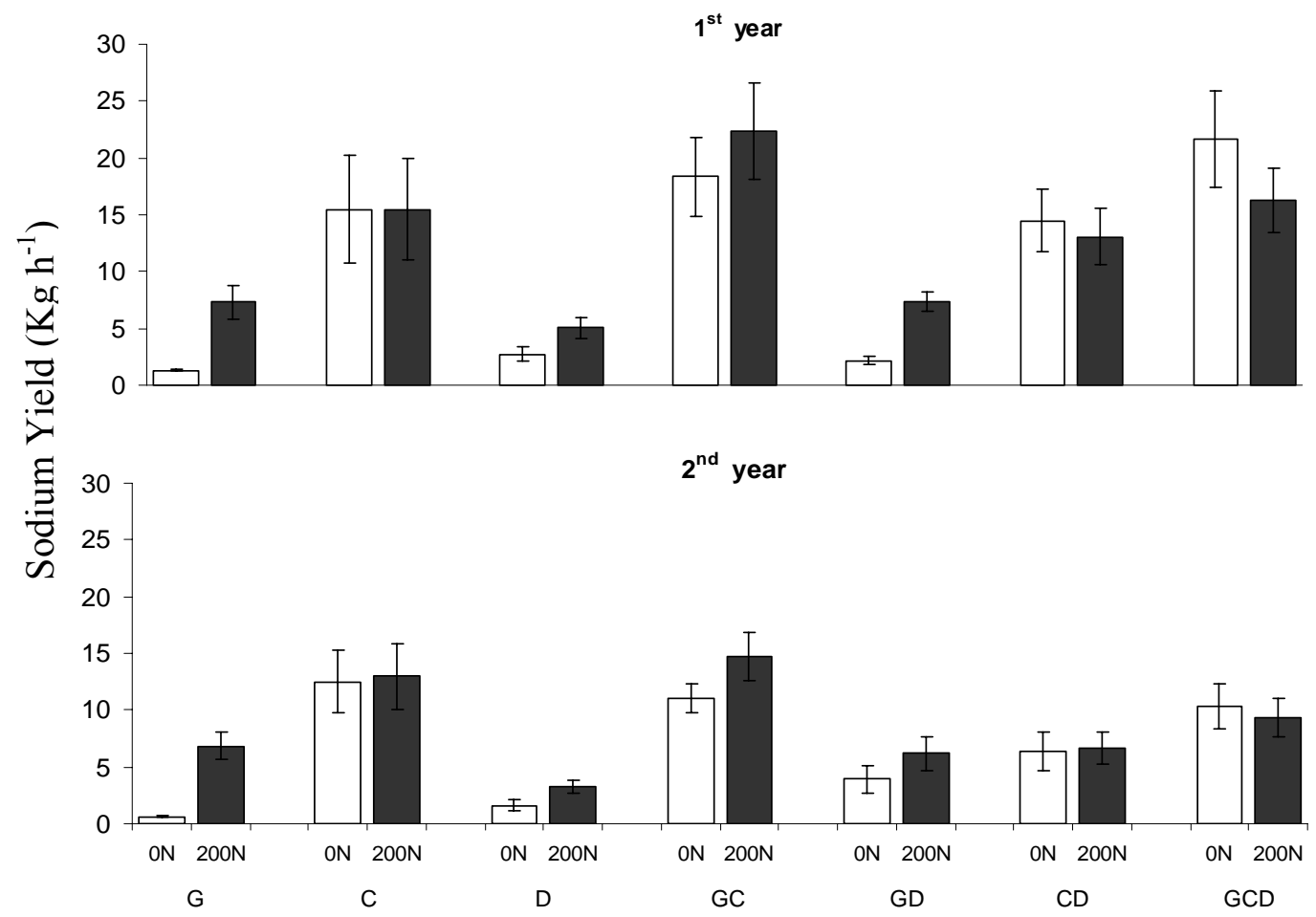

Figure 4.5 Mineral yield of $\mathrm{Na}\left(\mathrm{kg} \mathrm{ha}^{-1}\right)$ in herbage of pure stand and mixtures of ryegrass $(\mathrm{G})$, white clover $(\mathrm{C})$, and dandelion (D) growing under two $\mathrm{N}$ rates $\left(0\right.$ and $\left.200 \mathrm{~kg} \mathrm{ha}^{-1}\right)$ for two subsequent years (vertical bars indicate $+/$ s.e.m.). 


\subsection{Discussion}

In the present research, we investigated the influence of species composition and $\mathrm{N}$ fertilization on nutrients retention from the soil addressed via the mineral yield of $\mathrm{Ca}, \mathrm{Mg}, \mathrm{K}$, $\mathrm{P}$ and $\mathrm{Na}$ in the herbage. The effect of $\mathrm{N}$ fertilization varies among the tested minerals and among the grown swards. The effect of composition is more obvious when comparing the mixtures with the monocultures, where mixture generally produced higher herbage mineral yield than the monocultures. In addition, differences among mixture in terms of mineral yields were also found.

Our results show that among monocultures, white clover produced the highest herbage mineral yield $\left(\mathrm{kg} \mathrm{ha}^{-1}\right)$ for the most tested minerals, followed by dandelion and ryegrass, respectively (Figures 4.1-4.5), while dandelion herbage contains higher minerals concentrations $\left(\mathrm{g} \mathrm{kg}^{-1} \mathrm{DM}\right)$ than ryegrass (Table 4.2). These results indicate the importance of white clover in pastures as a source of minerals for the animals in addition to the fact that dandelion herbage quality in terms of the tested minerals is higher than ryegrass. Nitrogen application had a positive effect on the herbage mineral yield of ryegrass and dandelion monocultures but not on the herbage mineral yield of white clover. This can be explained with regards to the positive effect of $\mathrm{N}$ fertilization on the biomass production of the ryegrass and the dandelion monocultures, where biomass production of white clover was not significantly affected by $\mathrm{N}$ fertilization (data not shown here).

The complementarity of resource use and the differentiation between species in the mixtures may explain the lower herbage mineral yield of ryegrass and dandelion monocultures compared to the binary and the three-species mixtures (Bazzaz, 1987; Vandermeer, 1989). The above explanation can also be applied to the higher $\mathrm{Ca}$ and $\mathrm{Mg}$ yields of the three-species mixture compared to the binary mixture of ryegrass and white clover in the second year.

Generally, our results indicated that the presence of dandelion in forage mixtures may enhance herbage mineral yields compared to ryegrass monoculture or ryegrass-white clover mixture. Our results agree with that observed by Fisher et al. (1996) who found that the presence of forb species in swards resulted in higher contents of minerals in herbage compared to the grass-only mixtures. In the present experiment, dandelion monoculture produced higher $\mathrm{Ca}$ and $\mathrm{Mg}$ yields compared to ryegrass monoculture (Figures 4.1 and 4.2), hence, the presence of dandelion in the three-species mixture and in the binary mixtures 
enhanced $\mathrm{Ca}$ and $\mathrm{Mg}$ yield compared to the ryegrass-white clover mixture, especially in the second year. This effect was more obvious in the second year because the proportion of dandelion in the mixtures was significantly higher in the second year compared to the first one (data not shown here).

The effect of $\mathrm{N}$ application on the content of the minerals in the herbage varied among the tested minerals. Calcium yield was decreased in most mixtures by $\mathrm{N}$ application, while $\mathrm{Mg}$, $\mathrm{K}$, and $\mathrm{P}$ yields were significantly increased. Previous experiments have shown contradicting results regarding the effect $\mathrm{N}$ application on herbage mineral yield of $\mathrm{K}$ and $\mathrm{P}$ (Lambert \& Toussaint, 1978; Hopkins et al., 1994; Jolley, 1972; McKenzie \& Jacobs, 2002). However, most experiments studied the effect of $\mathrm{N}$ of nutrients concentration in herbage not on the herbage mineral yield. The positive effect of $\mathrm{N}$ application can be explained with regards to the fact that the amount of minerals that needed by plants depends on $\mathrm{N}$ supply, where $\mathrm{N}$ enhances plant growth and increases the demand for other nutrients (Wilkinson et al., 2000). Therefore, the positive relationship between $\mathrm{N}$ fertilization and the herbage mineral yield of $\mathrm{Ca}, \mathrm{P}$ and $\mathrm{K}$ in our experiment can be explained by the increase in total biomass yield of ryegrass-white clover, ryegrass-dandelion and the three-species mixture as a result of $\mathrm{N}$ application (data not shown here). In addition, $\mathrm{N}$ application might also increase mineral requirements for the plants by increasing root growth.

Our results regarding the positive effect of $\mathrm{N}$ application on $\mathrm{Na}$ yield of the ryegrass-white clover mixture agreed with the previous experiments which showed that Na yield of ryegrasswhite clover mixture is increased by $\mathrm{N}$ application (Hopkins et al., 1994; McKenzie \& Jacobs, 2002). The lower Na yield for the three-species mixture compared to that of ryegrass-white clover mixture might be attributed to the lower $\mathrm{Na}$ yield of dandelion compared to that of ryegrass and white clover.

Table 4.2 shows that $\mathrm{Ca}$ and $\mathrm{Mg}$ concentrations for all mixtures range from 6.5 to 26.0 and 1.8 to $6.0 \mathrm{~g} \mathrm{~kg}^{-1} \mathrm{DM}$, respectively. The lowest value is for the ryegrass monoculture and the highest for the dandelion monoculture. Calcium and $\mathrm{Mg}$ concentrations for all mixtures fall within the recommended concentration of $\mathrm{Ca}$ and $\mathrm{Mg}$ in herbage for the high producing dairy cows (Table 4.3). Potassium concentration in all mixtures ranges from 23.3 to $55.3 \mathrm{~g} \mathrm{~kg}^{-1} \mathrm{DM}$, which is much higher than the recommended concentration for dairy cows $\left(0.8 \mathrm{~g} \mathrm{~kg}^{-1} \mathrm{DM}\right.$; Table 4.3). For P, its concentration ranges from 3.5 to $7.8 \mathrm{~g} \mathrm{~kg}^{-1} \mathrm{DM}$, which falls within the 
recommended level for the animals (3.0 to $4.0 \mathrm{~g} \mathrm{~kg}^{-1} \mathrm{DM}$; Table 4.3). Across the two years, $\mathrm{Na}$ concentration was below the recommended level for the high diary cows $\left(1.2 \mathrm{~g} \mathrm{~kg}^{-1} \mathrm{DM}\right.$; Table 4.3) in ryegrass and dandelion monocultures as well as their binary mixtures especially without $\mathrm{N}$ fertilization.

\subsection{Conclusion}

Based on the above results, the current experiment concluded that dandelion as a constituent in the pasture might increase the quality of the herbage yield in terms of the tested minerals because it contains higher concentrations of minerals in herbage compared to the herbage of white clover or ryegrass. Although $\mathrm{N}$ fertilization increased herbage mineral yield of $\mathrm{Mg}, \mathrm{K}$, and $\mathrm{P}$, it had a negative effect on Ca yield and a non consistent effect on Na yield.

Complementarity and facilitation among the species in the mixtures was evident in the present experiment as most mixtures produced higher herbage mineral yield compared to the monocultures of ryegrass and dandelion. In addition, the three species mixtures which contained three different functional groups were generally outyielded the other mixtures, especially for $\mathrm{Ca}$ and $\mathrm{Mg}$. 


\section{General discussion}

In the present research, the effect of plant diversity on productivity and other functions of the ecosystem has been investigated in natural and semi-natural grasslands (chapter two) and in ley system (chapters 3 and 4). Both systems (permanent grasslands and ley system) have been combined together in one dissertation with regards to the recent findings that indicate a positive role of biodiversity in ecosystem functions and the suggestions to benefit from these results in agricultural systems (Kahmen et al., 2005; Sanderson et al., 2004). The positive relationship between biodiversity and productivity and nutrients retention (Huston 1997; Tilman et al., 1997; Hector et al., 1999; Loreau, 2000; Kahmen et al., 2005) does not only indicate a need to conserve plant species in natural ecosystems, but also urges the agronomists to apply these results to the managed grasslands and the grazed pastures.

Increasing species diversity of the managed grasslands and the cultivated pasture not only might increase the productivity, improve nutrients retention and recycling, reduce nutrients loss, increase resistance to invasion by exotic species, and increase the stability of the ecosystem against environmental fluctuation, but can also lead to a sustainable agriculture with low-input farming systems that minimize the use of external production inputs such as purchased fertilizers and pesticides. In the coming sections, I discuss, in a concise manner, the ideas behind the current experiments as well as the main results regarding the effect of biodiversity on productivity in the natural and semi-natural grasslands and in ley system.

\section{Biodiversity-productivity relationship in natural and semi-natural grasslands}

Most of the recent ecological experiments have used synthetic plant communities to explore the effect of species diversity on ecosystem functions. Before extrapolating the results of these experiments to the managed grasslands and pasture systems, the mechanisms behind their results must be identified as well as to investigate how this relationship is affected by the environmental factors. It has been argued that the results of these experiments might have little predictive value for the processes that occur in the natural ecosystem, where community composition, species loss and vegetation dynamics are not random but directed (Grime, 2002). Additionally, the effect of environmental factors in natural ecosystem is overwhelming compared to the effect of biodiversity (Wardle et al., 1997; Huston and McBride, 2002; Kahmen et al., 2005). 
The main result of the recent biodiversity-productivity experiments stated that there is an asymptotic increase in productivity along with increasing species richness. This result has been attributed mainly to complementarity among the species (Hector et al., 1999; hector et al., 2007). However, this result has been also attributed to the "sampling effect" and the immaturity of the swards. "Sampling effect" indicates an increased probability of including a highly productive species or a highly competitive one at the higher diversity levels (Huston, 1997). In addition, the immaturity of the swards produces results which are not reliable due to the fact that the turnover of the plant species in the artificially composed plant communities is much faster than the natural plant communities where the interspecific interaction has reached equilibrium.

In natural plant communities most observational studies showed that biodiversity reaches the peak at the intermediate productivity level, where high or low-productivity was always accompanied with low diversity levels. The contradiction in the results obtain from the experimental and the observational approaches has generated the current debate in which scientists disagree about the relative importance of declining species richness and its effect on ecosystem functioning (Loreau et al., 2001). Therefore, it has been suggested that there is a great need to use other approaches that is based on more "natural" ecosystems (Chapin et al., 2000; Loreau et al., 2001; Kahman et al., 2005).

To make the results of the recent experimental approach compatible with the observational one, it has been stated that the two approaches examine the effect of diversity and productivity under different set of conditions (Schmid, 2002). The observational approach tried to study the effect of productivity on species diversity across environmental gradients, where other factors such as soil fertility, climate, disturbance regime, or herbivory are correlated with the observed diversity and productivity levels. On the other hand, the recent experimental approach examines the effect of diversity on productivity within each site, when all these other factors are held constant.

In the present research, we have argued for the first time that the contradiction between the results of the experimental approach and the observational approach might be due to the fact that the general positive relationship between species richness and ecosystem productivity found by the experimental approach does not properly characterize the natural plant communities where the relationship could be driven by the environmental factors and the 
species composition and these factors might determine the response of the ecosystem to plant diversity. Our results indicated that there is no general relationship between plant diversity and productivity that is consistent for all sites and that the type of the diversity-productivity relationship could be influenced by the existing environmental conditions.

Our results indicated that there is a significant effect of evenness and species composition on the productivity of the natural and semi-natural grasslands, as community composition showed significant relationships with productivity for most of the surveyed sites. Community composition is a better measurement of biodiversity than species number as it combines several aspects of diversity such as species richness, evenness, species identity as well as the interactions among the species. The relationship between diversity and productivity of natural and semi-natural communities might be more related to species composition than to species number (Hooper \& Vitousek, 1997; Grime, 1997; Laird et al., 2003; Kahmen et al., 2005; Grace et al., 2007). Therefore, our results suggest that there is a need to include environmental factors in the future studies (rather than to control them) in order to investigate their effects on the biodiversity-productivity relationship and to use biodiversity measures that are more related to the processes of ecosystem like species composition and functional diversity.

\section{The effect of species diversity on productivity and nutrients retention in ley system}

We have investigated the potential effect of including dandelion on improving the performance of ryegrass/ white clover mixture in terms of total herbage yield, weed infestation and mineral herbage yield of $\mathrm{N}, \mathrm{Ca}, \mathrm{Mg}, \mathrm{K}, \mathrm{P}$ and $\mathrm{Na}$. In addition we have studied the competition between dandelion on one hand and white clover and ryegrass on the other hand (chapters three and four).

Depending on the findings from recent ecological research which suggested that ecosystem with a greater diversity of functional traits will operate more efficiently with higher productivity and resilience (Tilman et al., 1997; Hooper \& Vitousek, 1997), we have hypothesized that broadening the functional diversity of the traditional grass-clover mixture will increase the productivity, reduce weed infestation, and increase the quality of the harvested pasture by increasing the mineral contents in herbage.

Dandelion that grows in ryegrass-white clover mixture may add another functional variation to this mixture, for example, including deep- and shallow-rooted species in mixture could 
increase nutrient retention from deeper soil layers (Berendse, 1982; Sanderson et al., 2004). Other advantages might be also an improvement in the ensiling process, increasing in the mineral content, especially potassium $(\mathrm{K})$, and reduction in weed infestation of the sward through better exploitation of the available resources.

In a recent experiment done to investigate the effect of increasing the number of species on the productivity of pastures, Tracy \& Sanderson (2004a) found that mixtures with three or more species showed higher yields compared to one- and two-species mixtures. In addition, he concluded that optimal production could be achieved when growing three or four species mixtures, rather than more complex one. Thus, the productivity of the pasture might be increased by growing three or more species that are well adapted to the existing environmental conditions.

Regarding the herbage yield of the sown swards, an advantageous effect of dandelion was not evident in our experiment. This result can be attributed to the low contribution of dandelion to the herbage yield of the three-species mixture, especially in the first year. On the other hand, as a sign for overyielding of mixtures compared to monocultures (confirmed by the RYT analysis; Table 3.3) mixtures produced higher herbage yield compared to all monocultures. Generally, our results are in agreement with previous experiments which report that there is no yield advantage of complex mixtures over simple grass-legume mixtures (Annicchiarico et al., 1995; Tracy and Sanderson, 2004b).

In respect to the yield stability of the sown pastures over years, our results gives an indication that the presence of dandelion in mixtures led to a better pasture stability across time, where the lower temperature and precipitations in the second and third years compared to the first one (Table 3.1) might be responsible for the reduction in herbage yields of ryegrass and white clover. The higher contribution of dandelion to the herbage yield in the second and third years partly compensated for the reduction in ryegrass and white clover yield as dandelion is better adapted to drought conditions (Abu-Dieyeh and Watson, 2007). Previous experiments have also shown that yield stability of the pastures is affected by increasing species diversity (Naeem and Li, 1997; Tilman and Downing, 1994). Higher numbers of sown species may help in reducing yield fluctuation within and among growing seasons through compensation effects, where stress tolerant species compensate for the reduction in herbage yield of the other species under stress conditions (MacGillivray et al., 1995; Tracy and Sanderson, 2004a). 
In the present experiment, the biomass of the unsown species was significantly lower in the three-species mixture compared to white clover and dandelion monocultures as well as compared to ryegrass-dandelion and white clover-dandelion mixtures. This result is in agreement with other researches who found that increasing plant diversity, species evenness, and species composition might reduce weed invasion in pasture communities (Tracy and Sanderson, 2004b; Tracy et al., 2004; Kirwan et al., 2007). Furthermore, we have found that that dandelion herbage contains higher concentrations $\left(\mathrm{g} \mathrm{kg}^{-1} \mathrm{DM}\right)$ of $\mathrm{Mg}, \mathrm{K}$ and $\mathrm{P}$ compared to white clover and ryegrass.

In conclusion, dandelion might have the potential of contributing to herbage yield, yield stability, nutritive value, and weed resistance of ryegrass-white clover pastures. However, a better understanding of the management, attributes, and potential of dandelion would also give impetus for future experiments to consider other aspects such as pasture persistence, seasonal variation and tolerance to grazing. 


\section{References}

Abu-Dieyeh, M.H. \& Watson, A.K. (2007) Grass overseeding and a fungus combine to control Taraxacum officinale. Journal of Applied Ecology, 44, 115-124.

Annicchiarico, P., Bozzo, F., Parente, G., Gusmeroli, F., Mair, V., Marguerettaz, O. \& Orlandi, D. (1995) Analysis of adaptation of grass/legume mixtures to Italian alpine and subalpine zones through an additive main effects and multiplicative interaction model. Grass and Forage Science, 50, 405-413.

Barthram, G.T. \& Grant, S.A. (1994) Seasonal variation in growth characteristics of Lolium perenne and Trifolium repens in swards under different managements. Grass and Forage Science, 49, 487-495.

Bazzaz, F.A. (1987) Experimental studies on the evolution of niche in successional plant population.Pages 245-272 in A.J. Gray, M.J. Crawley, and P.J. Edwards, editors. Colonization, succession and stability. Blackwell Scientific, Oxford, UK.

Berendse, F. (1982) Competition between plant populations with differing rooting depths. III. field experiments. Oecologia, 53, 50-55.

Berry, P.M., Stockdale E.A., Sylvester-Bradley R., Philipps L., Smith K.A., Lord E.I., Watson C.A. \& Fortune S. (2003) N, P and K budgets for crop rotations on nine organic farms in the UK. Soil Use and Management, 19, 112-118.

Blaser, R.E., Skrdla, W.H. \& Taylor, T.H. (1952) Ecological and physiological factors in compounding seed mixtures. Advances in Agronomy, 4, 179-218.

Brummer, E.C. (1998) Diversity, stability, and sustainable American agriculture. Agronomy Journal, 90, 1-2.

Carlsson, G. \& Huss-Danell, K. (2003) Nitrogen fixation in perennial forage legumes in the field. Plant and Soil, 253, 353-372.

Chapin, F.S. III, Shaver, G.R, Giblin, A.E., Nadelhoffer, K.G. \& Laundre, J.A. (1995) Response of Arctic tundra to experimental and observed changes in climate. Ecology, $76,694-711$.

Chapin, F.S. III, Zavaleta, E.S., Eviner, V.T, Naylor, R.L., Vitousek, P.M., Sala O.E., Reynolds H.L., Hooper D.U., Mack M., Diaz S.E., Hobbie S.E. \& Lavorel S. (2000) Consequences of changing biodiversity. Nature, 405, 234-242.

Community Analysis Package Version 3.0 (2004) Designed by Henderson, P. A. \& Seaby, R. M. H. Pisces Conservation Ltd. Lymington, UK. 
Correll, O., Isselstein, J. \& Pavlu, V. (2003) Studying spatial and temporal dynamics of sward structure at low stocking densities: the use of an extended rising-plate-meter method. Grass and Forage Science, 58: 450-454.

Crawley, M.J., Brown, S.L., Heard, M.S. \& Edwards, G.R. (1999). Invasion-resistance in experimental grassland communities: species richness or species identity? Ecology Letters, 2, 140-148.

Crofts, A. \& Jefferson, R.G. (1994) The Lowland Grassland Management Handbook. Peterborough: English Nature/The Wildlife Trusts.

De Wit, C.T. (1960) On competition. Verslagen Landbouwkundige Onderzoekingen, 66, 182.

Diaz, S. \& Cabido, M. (2001) Vive la difference: plant functional diversity matters to ecosystem processes. Trends in Ecology and Evolution, 16, 646-655.

Donald, C.M. (1963) Competition among crop and pasture plants. Advances in Agronomy, $15,1-114$.

Elgersma, A., Schlepers, H. (1997) Performance of white clover/perennial ryegrass mixtures under cutting. Grass and Forage Science, 52, 134-146.

Faith, D.P., Minchin, P.R. \& Belbin, L. (1987) Compositional dissimilarity as a robust measure of ecological distance. Vegetatio, 69, 57-68.

Faurie, O., Soussana, J.F. \& Sinoquet, H. (1996) Radiation interception, partitioning and use in grass-clover mixtures. Annals of Botany, 77, 35-45.

Fisher, G.E.J., Baker L.J. \& Tiley G.E.D (1996) Herbage production from swards containing a range of grass, forb and clover species and under extensive management. Grass and Forage Science, 51, 58-72.

Fortune, S., Robinson, J.S., Watson, C.A., Philipps, L., Conway, J.S. \& Stockdale1, E.A. (2005) Response of organically managed grassland to available phosphorus and potassium in the soil and supplementary fertilization: field trials using grass-clover leys cut for silage. Soil Use and Management, 21, 370-376.

Fowler, N. (1982) Competition and coexistence in a North Carolina grassland. Journal of Ecology, 70, 77-92.

Gericke, S. \& Kurmies B. (1952) Die kolorimetrische Phosphorsäurenestimmung mit Ammonium-Vanadat-Molybdat und ihre Anwendung in der Pflanzenanalyse. Zeitschrift Pflanzenernährung, Düngung und Bodenkunde, 59, 235-247.

Grace, J.B., Anderson, M.T, Smith, M.D, Seabloom, E., Andelman, S.J., Meche, G., Weiher, E., Allain, L.K., Jutila, H., Sankaran, M, Knops, J., Ritchie, M., Michael R. \& Willig, 
M.R. (2007) Does species diversity limit productivity in natural grassland communities? Ecology Letters, 10, 680-689.

Grime, J.P. (1973) Competitive exclusion in herbaceous vegetation. Nature, 242, 344-347

Grime, J.P. (1997) Biodiversity and ecosystem function: the debate deepens. Science, 277, 1260-1261.

Grime, J.P. (2002) Declining plant diversity: empty niches or functional shifts? Journal of Vegetation Science, 13, 457-460.

Hakala, K. \& Jauhiainen L. (2007) Yield and nitrogen concentration of above- and below ground biomasses of red clover cultivars in pure stands and in mixtures with three grass species in northern Europe. Grass and Forage Science, 62, 312-321.

Haynes, R.J. (1980) Competition aspects of the grass-legume association. Advances in Agronomy, 33, 227-256.

Hector, A., Schmid, B., Beierkuhnlein, C., Caldeira, M.C., Diemer, M., Dimitrakopoulos, P.G., Finn, J.A., Freitas, H., Giller, P.S., Good, J., Harris, R., Högberg, P., HussDanell, K., Joshi, J., Jumpponen, A., Körner, C., Leadley, P.W., Loreau, M., Minns, A., Mulder, C.P.H., O’Donovan, G., Otway, S.J., Pereira, J.S., Prinz, A., Read, D.J., Scherer-Lorenzen, M., Schulze, E.-D., Siamantziouras, A.S.D., Spehn, E.M., Terry, A.C., Troumbis, A.Y., Woodward, F.I., Yachi, S. \& Lawton, J.H. (1999) Plant diversity and productivity experiments in European grasslands. Science, 28, 11231127.

Hector, A. \& Loreau, M. (2005) Relationships between biodiversity and production in grasslands at local and regional scales. In: McGilloway, D.A. (ed.), Grassland - a global resource. Wageningen Academic Publishers, Wageningen, pp. 295-304.

Hector, A., Joshi, J., Scherer-Lorenzen, M., Schmid, B., Spehn, E.M., Wacker, L., Weilenmann, M., Bazeley-White, E., Beierkuhnlein, C., Caldeira, M.C., Dimitrakopoulos, P.G., Finn, J., Huss-Danell, K., Jumpponen, A., Leadley, P.W., Loreau, M., Mulder, C.P.H., Neßhöver, C., Palmborg, C., Read, D.J., Siamantziouras, A.-S.D., Terry, A.C. \& Troumbis, A.Y. (2007) Biodiversity and ecosystem functioning: reconciling the results of experimental and observational studies. Functional Ecology, 21, 998-1002.

Hill, J.T.P., Michaelson-Yeates, T., 1987. Effects of competition upon the productivity of white clover-perennial ryegrass mixtures. Plant Breeding, 99, 239-250. 
Høgh-Jensen, H. \& Schjoerring, J.K. (1997) Interaction between white clover and ryegrass under contrasting nitrogen availability: $\mathrm{N} 2$ fixation, $\mathrm{N}$ fertilizer recovery, $\mathrm{N}$ transfer and water use efficiency. Plant and Soil, 197, 187-199.

Hooper, D.U. (1998) The role of complementarity and composition in ecosystem responses to variation in plant diversity. Ecology, 79, 704-719.

Hooper, D.U \& Vitousek, P.M. (1997) The effect of plant composition and diversity on ecosystem processes. Science, 277, 1302-1305.

Hooper, D.U. \& Vitousek, P.M. (1998) Effects of plant composition and diversity on nutrient cycling. Ecological Monograph, 68, 121-149.

Hooper, D.U., Chapin, F.S., Ewel, J.J., Hector, A., Inchausti, P., Lavorel, S., Lawton, J.H., Lodge, D.M., Loreau, M., Naeem, S., Schmid, B., Setala, H., Symstad, A.J., Vandermeer, J. \& Wardle, D.A. (2005) Effects of biodiversity on ecosystem functioning: a consensus of current knowledge. Ecological Monograph, 75, 3- 35.

Hopkins, A., Adamson, A.H. and Bowling, J.P. (1994) Response of permanent and reseeded grassland to fertilizer nitrogen. 2. Effects on concentrations of $\mathrm{Ca}, \mathrm{Mg}, \mathrm{K}, \mathrm{Na}, \mathrm{S}, \mathrm{P}$, $\mathrm{Mn}, \mathrm{Zn}, \mathrm{Cu}, \mathrm{Co}$ and Mo in herbage at a range of sites. Grass and Forage Science, 49, 9-20.

Huston, M.A. (1997) Hidden treatments in ecological experiments: re-evaluating the ecosystem function of biodiversity. Oecologia, 110, 449-460.

Huston, M.A., Aarssen, L.W., Austin, M.P., Cade, B.S., Fridley, J.D., Garnier, E., Grime, J.P., Hodgeson, J., Lauenroth, W.K., Thompson, K., Vandermeer, J.H. \& Wardle, D. (2000) No consistent effect of plant diversity on productivity. Science, 289, 1255.

Huston, M.A. \& McBride, A.C. (2002) Evaluating the relative strengths of biotic versus abiotic controls on ecosystem processes. In: Loreau M, Naeem S, Inchausti P (eds) Biodiversity and ecosystem functioning. Oxford University Press, New York, pp 4760.

Ives, A.R., King, J.L. \& Gross, K. (2000) Stability and species richness in complex communities. Ecology Letters, 3, 399-411.

Jolley, I.C. (1972) Mineral Composition of Pasture, and Grass Tetany of Cattle and Sheep. M. Agric. Sci. thesis, La Trobe University, Melbourne.

Jumpponen, A., Högberg, P., Huss-Danell, K. \& Mulder, C.P.H., 2002. Interspecific and spatial differences in nitrogen uptake in monocultures and two-species mixtures in north European grasslands. Functional Ecology, 16, 454-461. 
Kahmen, A., Perner, J., Audorff, V., Weisser, W. \& Buchmann, N. (2005) Effects of plant diversity, community composition and environmental parameters on productivity in montane European grasslands. Oecologia, 142, 606-615.

Kayser, M. and Isselstein, J. (2005) Potassium cycling and losses in grassland systems: a review. Grass and Forage Science, 60, 213-224.

Kenkel, N.C. \& Orloci, L. (1986) Applying Metric and Nonmetric Multidimensional Scaling to Ecological Studies: Some New Results. Ecology, 67, 919-928.

Kirwan, L., Lüscher, A., Sebastià, M.T., Finn, J.A., Collins, R.P., Porqueddu, C., Helgadottir, A., Baadshaug, O.H., Brophy, C., Coran, C., Dalmanndóttir, S., Delgado, I., Elgersma, A., Fothergill, M., Frankow-lindberg, B.E., Golinski, P., Grieu, P., Gustavsson, A.M., Höglind, M., Huguenin-elie, O., Iliadis, C., Jørgensen, M., Kadziuliene, Z., Karyotis, T., Lunnan, T., Malengier, M., Maltoni, S., Meyer, V., Nyfeler, D., Nykanen-Kurki, P., Parente, J., Smit, H. J., Thumm, U. \& Connolly, J. (2007) Evenness drives consistent diversity effects in intensive grassland systems across 28 European sites. Journal of Ecology, 95, 530-539.

Labreveux, M., Sanderson, M.A. \& Hall, M.H. (2006) Forage chicory and plantain: Nutritive value of herbage at variable grazing frequencies and intensities. Agronomy Journal, 98, 231-237.

Laird, R.A., Pither, J. \& Aarssen, L.W. (2003) Species evenness, not richness, has a consistent relationship with productivity in old-field vegetation. Community Ecology, 4, 21-28.

Lambert, J. and Toussaint, B. (1978) An investigation of the factors influencing the phosphorus content of herbage. Phosphorus in Agriculture, 73, 1-12.

Li, G.D. \& Kemp, P.D. (2005) Forage chicory (Cichorium intybus L.): A review of its agronomy and animal production. Advances of Agronomy, 88, 187-222.

Loiseau, P., Carrere, P., Lafarge, M., Delpy, R. and Dublanchet, J. (2001) Effect of soil-N and urine-N on nitrate leaching under pure grass, pure clover and mixed grass/clover swards. European Journal of Agronomy, 14,113-121.

Loreau, M. (2000) Biodiversity and ecosystem functioning: recent theoretical advances. Oikos, 91, 3-17.

Loreau, M. \& Hector, A. (2001) Partitioning selection and complementarity in diversity experiments. Nature, $412,72-76$. 
Loreau, M., Naeem, S., Inchausti, P., Grime, J.P., Hooper, D.U., Raffaelli, D., Schmid, B., Tilman, D. \& Wardle, D.A. (2001) Biodiversity and ecosystem functioning: current knowledge and future challenges. Science, 294, 804-808.

Loreau, M., Naeem, S. \& Inchausti, P. (2002) Biodiversity and Ecosystem Functioning: Synthesis and Perspectives. Oxford University Press, Oxford.

Ma, M. (2005) Species richness vs evenness: independent relationship and different responses to edaphic factors. Oikos, 111, 192-198.

MacGillivray, C.W., Grime, J.P., Band, S.R., Booth, R.E., Campbell, B., Hendry, G.A.F., Hillier, S.H., Hodgson, J.G., Hunt, R., Jalili, A., Mackey, J.M.L., Mowforth, M.A., Neal, A.M., Reader, R., Rorison, I.H., Spencer, R.E., Thompson, K., Thorpe, P.C. \& (1995) Testing predictions of the resistance and resilience of vegetation subjected to extreme events. Functional Ecology, 9, 640-649.

Magurran, A.E. (1988) Ecological diversity and its measurement. Princeton Univ. Press, Princeton, NJ.

McKenzie, F.R \& Jacobs, J.L. (2002) Effects of application of nitrogen fertilizer on concentrations of $\mathrm{P}, \mathrm{K}, \mathrm{S}, \mathrm{Ca}, \mathrm{Mg}, \mathrm{Na}, \mathrm{Cl}, \mathrm{Mn}, \mathrm{Fe}, \mathrm{Cu}$ and $\mathrm{Zn}$ in perennial ryegrass/white clover pastures in south-western Victoria, Australia. Grass and Forage Science, 57, 48-53.

McNaughton, S.J. (1977) Diversity and stability of ecological communities: A comment on the role of empiricism in ecology. The American Naturalist, 111, 512-515.

Minns, A., Finn, J., Hector, A., Caldeira, M., Joshi, J., Palmborg, C., Schmid, B., Scherer Lorenzen, M., Spehn, E. \& Troubis, A. (2001) The functioning of European grassland ecosystems: Potential benefits of biodiversity to agriculture. Outlook in Agriculture, $30,179-185$.

Naeem, S. \& Li, S. (1997) Biodiversity enhances ecosystem reliability. Nature, 390, 507-508.

Naeem, S., Thompson, L.J., Lawler, S.P., Lawton, J.H. \& Woodfin, R.M. (1994) Declining biodiversity can alter the performance of ecosystems. Nature, 368, 734-737.

Naeem, S., Hakansson, K., Lawton, J.H., Crawley, M.J. \& Thompson, L.J. (1996) Biodiversity and plant productivity in a model assemblage of plant species. Oikos, 76, 259-264.

Newton, J. (1993) Organic Grassland. pp128. Wye, Kent, UK. Chalcombe Publications.

Noss, R. (1990) Indicators for Monitoring Biodiversity: A Hierarchal Approach. Conservation Biology, 4, 355-364. 
Ofori, F. \& Stern, W.R. (1987) Cereal-legume intercropping systems. Advances in Agronomy, 41, 41-90.

Piepho, H.P., Büchse, A. \& Emrich, K (2003) A hitchhiker's guide to mixed models for randomized experiments. Journal of Agronomy and Crop Science, 189, 310-322.

Piepho, H.P., Büchse, A. \& Richter, C. (2004) A mixed modeling approach for randomized experiments with repeated measures. Journal of Agronomy and Crop Science, 190, 230-247.

Rochon, J. J., Doyle, C. J., Greef, J. M., Hopkins, A., Molle, G., Sitzia, M. \& Scholefield, D. (2004) Grazing legumes in Europe: a review of their status, management, benefits, research needs and future prospects. Grass and Forage Science, 59, 197-214.

Sanderson, M.A. \& Elwinger, G.F. (1999) Grass species and cultivar effects on establishment of grass-white clover mixtures. Agronomy Journal, 9, 889-897.

Sanderson, M.A., Skinner, R.H., Barker, D.J., Edwards, G.R., Tracy, B.F. \& Wedin, D.A. (2004) Plant species diversity and management of temperate forage and grazing land ecosystems. Crop Science, 44, 1132-1144.

Schinkel, H. (1984) Bestimmung von Calcium, Strontium, Kalium, Natrium, Lithium, Eisen, Mangan, Chrom, Nickel, Kupfer, Cobalt, Zink und Cadmium. Analytische Chemie, $317,10-26$.

Schmid, B. (2002) The species richness-productivity controversy. Trends in Ecology and Evolution, 17, 113114.

Schwank, O., Blum, H. \& Nösberger, J. (1986) The influence of irradiance distribution on the growth of white clover (Trifolium repens L.) in differently managed canopies of permanent grassland. Annals of Botany 57, 273-281.

Sheldrick, R.D. (2000) Sward establishment and renovation. In: Hopkins A. (ed.) Grass - its production and utilisation. Blackwell Science, Oxford, UK, pp. 13-30.

Smith, V.H., Tilman, G.D. \& Nekola, J.C. (1999) Eutrophication: Impacts of excess nutrient inputs on freshwater, marine, and terrestrial ecosystems. Environmental Pollution, 100, 179-196.

Sölter, U, Hopkins, A., Sitzia, M., Goby, J.P. \& Greef, J.M. (2007) Seasonal changes in herbage mass and nutritive value of a range of grazed legume swards under Mediterranean and cool temperate conditions. Grass and Forage Science, 62, 372-388.

Spehn, E.M., Scherer-Lorenzen, M., Schmid, B., Hector, A., Caldeira, M.C., Dimitrakopoulos, P.G., Finn, J.A., Jumpponen, A., O'Donnovan, G., Pereira, J.S., Schulze, E.-D., Troumbis, A.Y. \& Körner, C. (2002). The role of legumes as a 
component of biodiversity in a cross-European study of grassland biomass nitrogen. Oikos, 98, 205-218.

Spellerberg, I.F., Goldsmith, F.B. \& Morris, M.G. (1991) The scientific management of temperate communities for conservation. Black well Scientific Publications, Oxford, UK.

SPSS Inc. (2001) SPSS Base 11.0 user's guide. SPSS, Chicago.

Stewart-Wade, S.M., Neumann, S., Collins, L. \& Boland, G.J. (2002) The biology of Canadian weeds. 117. Taraxacum officinale G.H. Weber ex Wiggers. Canadian Journal of Plant Science, 82, 825-853.

Stirling, G. \& Wilsey, B. (2001) Empirical relationships between species richness, evenness, and proportional diversity. The American Naturalist, 158, 286-299.

Symstad, A.J. \& Tilman, D. (2001) Diversity loss, recruitment limitation, and ecosystem functioning: lessons learned from a removal experiment. Oikos, 92, 424-435.

Tallowin, J.R.B. \& Brookman, S.E.K. (1996) The impact of differences in nitrogen content, nitrogen utilisation and loss from laminae on competition between four grass species in an old pasture. Journal of Agricultural Science, Cambridge, 126, 25-35.

Tilman, D. (1997) Community invasibility, recruitment limitation, and grassland biodiversity. Ecology, 78, 81-92.

Tilman, D. (1999) The ecological consequences of changes in biodiversity: A search for general principles. Ecology, 80, 1455-1474.

Tilman, D., Wedin, D. \& Knops, J. (1996) Productivity and sustainability influenced by biodiversity in grassland ecosystems. Nature, 379, 718-720.

Tilman, D., Lehman, C.L. \& Thomson, K.T. (1997) Plant diversity and ecosystem productivity: Theoretical considerations. Proceedings of The National Academy of Sciences of The United States of America, 94, 1857-1861.

Tilman, G.D. (1999) The ecological consequences of changes in biodiversity: A search for general principles. Ecology, 80, 1455-1474.

Tracy, B.F. \& Sanderson, M.A. (2004a) Productivity and stability relationships in mowed pastures of varying species composition. Crop Science, 44, 2180-2186.

Tracy, B.F. \& Sanderson, M.A. (2004b) Forage productivity, species evenness and weed invasion in pasture communities. Agriculture, Ecosystems and Environment, 102, $175-183$. 
Tracy, B.F., Renne, I., Gerrish, J. \& Sanderson, M.A. (2004) Effects of plants diversity on invasion of weed species in experimental pasture communities. Basic and Applied Ecology, 5, 543-550.

Vandermeer, J.H. (1989) The ecology of intercropping. Cambridge University Press, New York, USA.

Vinton, M.A. \& Burke I.C. (1995) Interactions between individual plant species and soil nutrient status in short-grass-steppe. Ecology, 76,1116-1133.

Vitousek, P.M. \& Walker L.R. (1989) Biological invasion by Myrica faya in Hawai'i: plant demography, nitrogen fixation, ecosystem effects. Ecological Monograph, 59, 247265.

Vitousek, P.M. \& Hooper, D.U. (1993) Biological diversity and terrestrial ecosystem biogeochemistry. In: Schulze E.-D. and Mooney H.A. (eds.). Biodiversity and ecosystem function. Springer-Verlag, Berlin, Germany, pp. 3-14.

Wardle, D.A. (1999) Is "sampling effect" a problem for experiments investigating biodiversity ecosystem function relationship? Oikos, 87, 403-407.

Wardle, D.A., Bonner, K.I. \& Nicholson, K.S. (1997). Biodiversity and plant litter: Experimental evidence which does not support the view that enhanced species richness improves ecosystem function. Oikos, 79, 247-258.

Watkinson, A.R. \& Ormerod, S.J. (2001) Grasslands, grazing and biodiversity: Editors' introduction. Journal of Applied Ecology, 38, 233-237.

Wedin, D.A. \& Tilman, D. (1990) Species effects on nitrogen cycling: a test with perennial grasses. Oecologia, 84, 433-441.

Whalley, R.D.B. \& Hardy, M.B. (2000) Measuring botanical composition of grasslands. In: 't Mannetje L. and Jones R.M. (eds) Field and Laboratory Methods for Grassland and Animal Production Research, pp. 67-102. Wallingford, UK: CAB International.

Wilkinson, S.R., Grunes, D.L. \& Sumner, M.E. (2000) Nutrient interactions in soil and plant nutrition. In: Sumner M.E. (ed.) Handbook of Soil Science, pp. D89- D112. Boca Raton, FL, USA: CRC Press.

Williams, A.C. \& McCarthy, B.C. (2001) A new index of interspecific competition for replacement and additive designs. Ecological Research, 16, 29-40.

Wilsey, B.J. \& Potvin, C. (2000) Biodiversity and ecosystem functioning: importance of species evenness in an old field. Ecology, 81, 887-892.

Wilsey, B.J. \& Polley, H.W. (2002) Reductions in grassland species evenness increase dicot seeding invasion and spittle bug infestation. Ecology Letters, 5, 676-684. 
Yachi, S. \& Loreau, M. (2001) Biodiversity and ecosystem productivity in a fluctuating environment: The insurance hypothesis. Proceedings of The National Academy of Sciences of The United States of America, 96, 1463-1468.

Zemenchik, R.A, Albrecht, K.A., Schultz, M.K. \& (2001) Nitrogen replacement values of Kura Clover and Birdsfoot Trefoil in mixtures with cool-season grasses. Agronomy Journal, 93, 451-458. 


\section{$7 \quad$ Publications}

Assaf, T.A, Beyschlag, W. \& Isselstein, J. (submitted) Species composition and environmental conditions determine the relationship between plant diversity and productivity of natural and semi-natural grasslands. Functional Ecology.

Assaf, T.A \& Isselstein, J. (submitted) The effect of dandelion (Taraxacum officinale Web.) as a constituent of seed mixtures on herbage production and weed infestation of perennial ryegrass-white clover swards. Crop Science. 


\section{$8 \quad$ Curriculum vitae}

\section{Personal Information}

$\begin{array}{ll}\text { Name: } & \text { Taher A. Assaf } \\ \text { Nationality: } & \text { Jordanian } \\ \text { Date of birth: } & 09.11 .76 \\ \text { Place of birth: } & \text { Irbid, Jordan } \\ \text { Current Address: Wellensiek 89, 33619, Bielefeld } \\ \text { E-mail address: } & \text { tassaf@gwdg.de; taher_assaf@hotmail.com }\end{array}$

\section{School Education}

1982-1993 Primary and secondary school (Irbid, Jordan)

1993-1994 General Secondary Education Certificate (Avg. 82.6)

Irbid, Jordan. 1994.

\section{University Education}

2004-2008 Studying for obtaining Ph.D. degree at Grassland Science Department, Institute of Agronomy and Plant Breeding, Georg-August University, Göttingen, Germany.

1998-2001 Jordan University of Science and Technology, Jordan.

Plant Production, Field Crop Production,

Ms.C. (Avg. 90.8), 2001.

1994-1998 Jordan University of Science and Technology, Jordan.

Plant Production. B.Sc. (Avg. 81.3).

\section{Professional Career}

2003-2004

Teacher Assistant, Plant production Faculty, Mutah University, Jordan.

Teaching practical laboratories of various courses.

2002-2003 Private company, Nursery Management.

1998-2000 Teaching Assistance in Plant Production Laboratory, Jordan University of Science and Technology (part time).

\section{Languages}

Arabic

Mother Language

English

Fluent

Deutsch

Elementary 